\title{
15d-PGJ 2 Promotes ROS-Dependent Activation of MAPK-Induced Early Apoptosis in Osteosarcoma Cell In Vitro and in an Ex Ovo CAM Assay
}

\author{
Mateja Mikulčić ${ }^{1} \mathbb{D}$, Nassim Ghaffari Tabrizi-Wizsy ${ }^{2}$, Eva M. Bernhart ${ }^{3}$, Martin Asslaber ${ }^{4}$, \\ Christopher Trummer ${ }^{3,5}$, Werner Windischhofer ${ }^{5}$, Wolfgang Sattler ${ }^{3}$, Ernst Malle ${ }^{3}$ and Andelko Hrzenjak ${ }^{1,6, *}$ (1) \\ 1 Department of Internal Medicine, Division of Pulmonology, Medical University of Graz, 8036 Graz, Austria; \\ mateja.mikulcic@medunigraz.at \\ 2 Otto Loewi Research Center, Division of Immunology and Pathophysiology, Medical University of Graz, \\ 8010 Graz, Austria; nassim.ghaffari@medunigraz.at \\ 3 Gottfried Schatz Research Center, Division of Molecular Biology and Biochemistry, Medical University of Graz, \\ 8010 Graz, Austria; eva.bernhar@@medunigraz.at (E.M.B.); christopher.trummer@medunigraz.at (C.T.); \\ wolfgang.sattler@medunigraz.at (W.S.); ernst.malle@medunigraz.at (E.M.) \\ 4 Diagnostic and Research Institute of Pathology, Medical University of Graz, 8010 Graz, Austria; \\ martin.asslaber@medunigraz.at \\ 5 Department of Pediatrics and Adolescence Medicine, Medical University of Graz, 8036 Graz, Austria; \\ werner.windischhofer@medunigraz.at \\ 6 Ludwig Boltzmann Institute for Lung Vascular Research, Medical University of Graz, 8010 Graz, Austria \\ * Correspondence: andelko.hrzenjak@medunigraz.at; Tel.: +43-316-385-73860
}

Citation: Mikulčić, M.;

Tabrizi-Wizsy, N.G.; Bernhart, E.M.; Asslaber, M.; Trummer, C.;

Windischhofer, W.; Sattler, W.;

Malle, E.; Hrzenjak, A. 15d-PGJ 2

Promotes ROS-Dependent Activation of MAPK-Induced Early Apoptosis in Osteosarcoma Cell In Vitro and in an Ex Ovo CAM Assay. Int. J. Mol. Sci. 2021, 22, 11760. https://doi.org/ 10.3390/ijms222111760

Academic Editor: Peter J.K. Kuppen

Received: 29 September 2021

Accepted: 26 October 2021

Published: 29 October 2021

Publisher's Note: MDPI stays neutral with regard to jurisdictional claims in published maps and institutional affiliations.

Copyright: () 2021 by the authors. Licensee MDPI, Basel, Switzerland. This article is an open access article distributed under the terms and conditions of the Creative Commons Attribution (CC BY) license (https:// creativecommons.org/licenses/by/ $4.0 /)$.
Abstract: Osteosarcoma (OS) is the most common type of bone tumor, and has limited therapy options. 15-Deoxy- $\Delta^{12,14}$-prostaglandin $\mathrm{J}_{2}\left(15 \mathrm{~d}-\mathrm{PGJ}_{2}\right)$ has striking anti-tumor effects in various tumors. Here, we investigated molecular mechanisms that mediate anti-tumor effects of $15 \mathrm{~d}-\mathrm{PGJ}_{2}$ in different OS cell lines. Human U2-OS and Saos-2 cells were treated with 15d-PGJ 2 and cell survival was measured by MTT assay. Cell proliferation and motility were investigated by scratch assay, the tumorigenic capacity by colony forming assay. Intracellular ROS was estimated by $\mathrm{H}_{2}$ DCFDA. Activation of MAPKs and cytoprotective proteins was detected by immunoblotting. Apoptosis was detected by immunoblotting and Annexin V/PI staining. The ex ovo CAM model was used to study growth capability of grafted $15 \mathrm{~d}-\mathrm{PGJ}_{2}$-treated OS cells, followed by immunohistochemistry with hematoxylin/eosin and Ki-67. 15d-PGJ 2 substantially decreased cell viability, colony formation and wound closure capability of OS cells. Non-malignant human osteoblast was less affected by $15 \mathrm{~d}-\mathrm{PGJ}_{2}$. 15d-PGJ 2 induced rapid intracellular ROS production and time-dependent activation of MAPKs (pERK1/2, pJNK and pp38). Tempol efficiently inhibited 15d-PGJ 2 -induced ERK1/2 activation, while $\mathrm{N}$-acetylcystein and pyrrolidine dithiocarbamate were less effective. Early but weak activation of cytoprotective proteins was overrun by induction of apoptosis. A structural analogue, 9,10-dihydro-15d-PGJ 2 , did not show toxic effects in OS cells. In the CAM model, we grafted OS tumors with U2-OS, Saos-2 and MG-63 cells. 15d-PGJ 2 treatment resulted in significant growth inhibition, diminished tumor tissue density, and reduced tumor cell proliferation for all cell lines. Our in vitro and CAM data suggest $15 \mathrm{~d}-\mathrm{PGJ}_{2}$ as a promising natural compound to interfere with OS tumor growth.

Keywords: $15 \mathrm{~d}-\mathrm{PGJ}{ }_{2}$; apoptosis; CAM assay; osteosarcoma; reactive oxygen species

\section{Introduction}

Osteosarcoma (OS), a tumor of mesenchymal origin, represents the most common primary malignancy of bones and the most frequent malignant bone tumor $[1,2]$. OS occurs predominantly in adolescents and is the eighth most common pediatric cancer. Despite well-established therapy protocols, patients suffering from this high-grade malignant tumor have a very poor survival rate. Patients with localized disease have a 5-year overall 
survival of $60-70 \%$ [3-5], however, recurrences are frequent and develop in $40-50 \%$ of patients during treatment $[6,7]$. Beside surgery, neoadjuvant therapy based on combination of methotrexate-doxorubicin-cisplatin is established, albeit very aggressive and toxic [8]. Therefore, not only optimization of current therapy protocols, but also discovery of alternative strategies and development of novel therapeutic approaches are required. Currently, several ongoing clinical trials are evaluating treatment strategies to improve the unfavorable prognosis for high-grade osteosarcoma patients undergoing conventional treatment $[9,10]$. Thus, a better understanding of molecular mechanisms involved in OS tumorigenesis is essential.

Besides genetic alterations [4], etiological factors such as cyclooxygenase and its respective metabolites, the prostaglandins (PGs), are pivotal bioactive molecules involved in bone resorption [11] and bone formation [12,13], but also in bone patho/physiology and tumorigenesis. $\mathrm{PGE}_{2}$, the most abundant PG species synthesized by various solid tumors, acts as a potent modulator of tumor cell proliferation, angiogenesis, invasion and immunosuppression [14]. However, $\mathrm{PGD}_{2}$ has also been shown to modulate osteoclast and osteoblast function in vivo and in vitro [11,15]. $\mathrm{PGD}_{2}$ is highly unstable under in vivo and in vitro conditions, although reported to contribute to cellular migration, apoptosis, and matrix calcification of bone tissue [16,17]. Interestingly, the final but stable degradation product of $\mathrm{PGD}_{2}, 15$-deoxy- $\Delta^{12,14}-\mathrm{PGJ}_{2}\left(15 \mathrm{~d}-\mathrm{PGJ}_{2}\right)$, has been shown to regulate a variety of cellular events ranging from cell growth to apoptosis [18]. These characteristics of $15 \mathrm{~d}-\mathrm{PGJ}_{2}$ are based on its electrophilic character as the $\alpha, \beta$-unsaturated ketone moiety may form covalent protein adducts via Michael addition with cellular nucleophiles, preferentially thiol groups. Under basal conditions, picomolar to nanomolar concentrations (and even higher) of free $15 \mathrm{~d}-\mathrm{PGJ}_{2}$ have been measured in biological fluids [19], whereas increased cyclic PG levels have been reported during late stages of inflammation and cancer [20]. Effects of $15 \mathrm{~d}-\mathrm{PGJ}_{2}$ have been reported in different cellular systems. Cytotoxic effects of 15d-PGJ 2 have been described in uterine cancer [21], breast cancer [22], prostate cancer [23], colon cancer [24], and to a certain extent also in OS cells [25,26]. Our group showed that in MG-63 OS cells, these cytotoxic effects are based on the activation of the mitogenactivated protein kinase (MAPK) / Akt axis [25], whereas Yen and coworkers showed that $15 \mathrm{~d}_{-} \mathrm{PGJ}_{2}$ induces reactive oxygen species (ROS)-mediated Akt inhibition and cell cycle alterations [26]. However, the acute effects of $15 \mathrm{~d}-\mathrm{PGJ}_{2}$ and its molecular mechanism in other OS cells are still not described.

In the present study, we demonstrated that $15 \mathrm{~d}-\mathrm{PGJ}_{2}$ has pronounced cytotoxic effects in U2-OS and Saos-2 OS cell lines. These effects were mainly based on ROS-mediated apoptosis and were more pronounced in OS cell lines as compared to a non-malignant osteoblast cell line. Furthermore, we showed substantial inhibitory effects of $15 \mathrm{~d}-\mathrm{PGJ}_{2}$ on OS-tumor growth by employing the avian ex ovo chorioallantoic membrane (CAM) assay, providing an important step towards preclinical in vivo models that meet $3 \mathrm{R}$ requirements and allow high throughput development of new treatment modalities.

\section{Results}

\section{1. $15 d-P G J_{2}$ Inhibits the Cell Growth, Colony Formation, and Motility of Human OS Cells}

U2-OS and Saos-2 cells were treated with $20 \mu \mathrm{M} 15 \mathrm{~d}-\mathrm{PGJ}_{2}$, based on data published in our previous study [25]. Experiments with a human osteoblastic cell line (hFOB1.19) were included to figure out any difference between non-malignant and OS cell lines in response to 15d-PGJ 2 . As shown in Figure 1A, both U2-OS and Saos-2 OS cell lines showed significantly reduced viability already $4 \mathrm{~h}$ after the treatment by $37 \%$ (U2-OS) and $80 \%$ (Saos-2), respectively. This reduction was even more pronounced after $24 \mathrm{~h}$, with $16 \%$ (U2-OS) and 2\% (Saos-2) remaining cell viability. Cell viability of non-malignant human osteoblastic hFOB1.19 cells was reduced by $10 \%(4 \mathrm{~h})$ and by $75 \%(24 \mathrm{~h})$ following treatment with $15 \mathrm{~d}-\mathrm{PGJ}_{2}$. Summarized, non-malignant osteoblast cells showed a substantially milder response towards $15 \mathrm{~d}-\mathrm{PG} \mathrm{J}_{2}$ treatment when compared to both OS cell lines and cell viability was decreased in the following order: Saos-2 >> U2-OS > hFOB1.19. These results were 
supported by morphological changes in all three cell lines, hFOB1.19 cells showing the least pronounced effect in response to $15 \mathrm{~d}-\mathrm{PGJ}_{2}$ (Figure 1B).
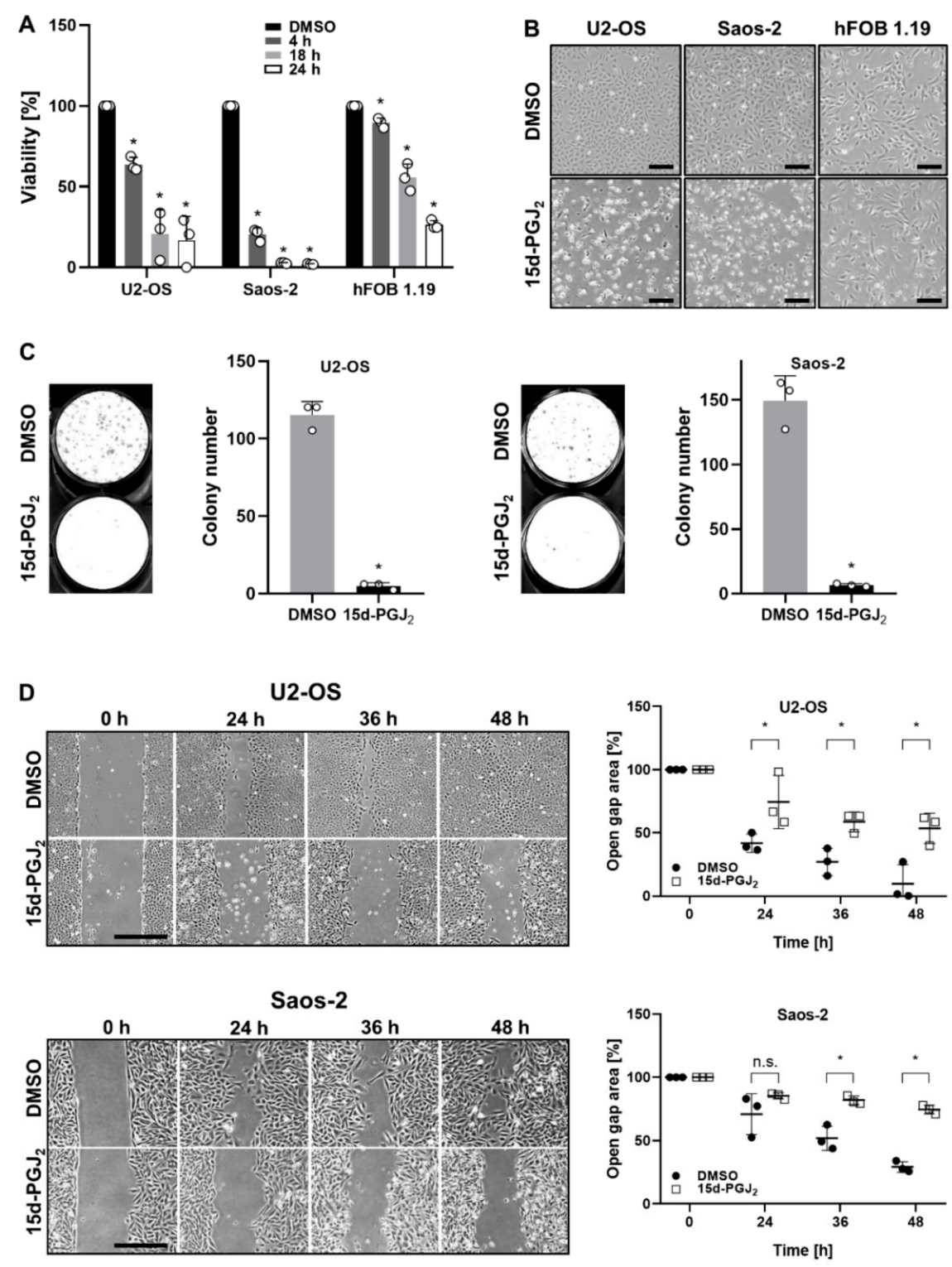

Figure 1. 15d-PGJ 2 inhibits cell growth, colony forming ability and motility of OS cell lines. (A) Human OS cell lines (U2-OS and Saos-2) and the human non-malignant osteoblastic cell line hFOB 1.19 were treated with $20 \mu \mathrm{M} 15 \mathrm{~d}-\mathrm{PGJ}_{2}$ for indicated time periods. Cell viability was measured by MTT proliferation assay. DMSO concentration corresponding to the $20 \mu \mathrm{M}$ $15 \mathrm{~d}-\mathrm{PGJ}_{2}(0.04 \%)$ was used as a vehicle control. Data are represented as means of three independent experiments and viability of DMSO-treated cells was set to $100 \%\left({ }^{*} p \leq 0.05\right)$. (B) Representative images display the change in morphology of OS and hFOB 1.19 cell lines observed upon treatment with $20 \mu \mathrm{M} 15 \mathrm{~d}-\mathrm{PGJ}_{2}$ for $24 \mathrm{~h}$. (scale bar $=100 \mu \mathrm{m}$ ). (C) Representative images (left panel) and bar graphs (right panel) out of three experiments show significant differences between the number of colonies formed by U2-OS and Saos-2 cells after a 10 and 15 day incubation, respectively. Both cell lines were treated for $24 \mathrm{~h}$ with $20 \mu \mathrm{M}$ 15d-PGJ 2 dissolved in DMSO. DMSO (0.04\%) was used as vehicle control. (D) U2-OS (upper panel) and Saos-2 OS (lower panel) cells were seeded into 12-well plates containing cell culture inserts with a $500 \mu \mathrm{m}$ cell-free gap and grown until approx. $90 \%$ confluence before $24 \mathrm{~h}$ treatment with $15 \mathrm{~d}-\mathrm{PGJ}_{2}$ or DMSO $(0.04 \%)$ as vehicle control. Inserts were removed and the gap closure was measured and quantified at indicated time periods. Representative images and dot graphs for each cell line (performed in triplicates) are shown. Scale bar $=500 \mu \mathrm{m}$. The dot graphs display the differences in scratch closure at each time point, with zero time point set to $100 \%$. Data are represented as means \pm SD. ${ }^{*} p \leq 0.05$; n.s. = not significant). 
The colony-formation assay was performed to further underscore the malignant potential of Saos-2 and U2-OS cell lines after treatment with $15 \mathrm{~d}-\mathrm{PGJ}_{2}$. Figure $1 \mathrm{C}$ shows a strongly diminished potential for colony formation of both OS cell lines in response to $24 \mathrm{~h}$ $15 \mathrm{~d}-\mathrm{PGJ}_{2}$ treatment. Upon $15 \mathrm{~d}-\mathrm{PGJ}_{2}$ treatment, only few OS cells survived being able to form colonies, which is indicative for a pronounced anti-tumorigenic effect of $15 \mathrm{~d}-\mathrm{PGJ} \mathrm{J}_{2}$ towards OS cells.

In order to investigate the influence of $15 \mathrm{~d}-\mathrm{PGJ}_{2}$ on proliferation and motility of U2-OS and Saos-2 cells, a wound healing (scratch) assay was performed. Our data showed significant differences in wound closure between vehicle-treated and $15 \mathrm{~d}-\mathrm{PGJ}_{2}$-treated OS cells, these differences being more pronounced in U2-OS as compared to Saos-2 cells (Figure 1D). These effects were based predominantly on diminished cell proliferation upon $15 \mathrm{~d}-\mathrm{PGJ}_{2}$ treatment and, at least partially, on altered cell motility. In vehicle-treated OS cell lines, amorphous scratch borders with outgrowing cells were observed over time. In contrast, in $15 \mathrm{~d}-\mathrm{PGJ}_{2}$-treated samples scratch borders remained smooth during the whole observation period ( $48 \mathrm{~h})$, indicating altered cell motility.

\section{2. $15 d-P G J_{2}$-Induced ROS Production in OS Cells Can Be Inhibited by Specific ROS Inhibitors}

As previously reported by our group [25], 15d-PGJ ${ }_{2}$ induces ROS production in MG-63 OS cells. Here, we wanted to investigate whether $15 \mathrm{~d}-\mathrm{PGJ}_{2}$-induced ROS activation is an early event and a characteristic feature of U2-OS and Saos-2 OS cell lines. Our results indicate a fast, statistically significant, and time-dependent ROS generation at similar extent in both cell lines (Figure 2A). In order to assess the importance of the augmented ROS production to further downstream signaling events triggered by $15 \mathrm{~d}-\mathrm{PGJ}_{2}$, we checked the status of phosphorylation/activation of extracellular signal-regulated kinase (ERK1/2, also known as p42/44 MAPK), an event commonly mediated by an increase in ROS levels. We detected strong phosphorylation of ERK1/2 in both cell lines already 15 min upon treatment (Figure 2B). We further used three different ROS scavengers (NAC (N-acetyl-cysteine); PDTC (pyrrolidine dithiocarbamate), and Tempol) to interfere with phosphorylation of ERK1/2 (Figure 2B). Preincubation with NAC (a cell permeable thiol that restores intracellular glutathione) slightly decreased ERK1/2 phosphorylation in U2-OS but not Saos-2 cells. The metal chelating antioxidant compound PDTC reduced ERK1/2 phosphorylation in U2-OS cells but was without significant effect in Saos-2 cells. Tempol, a superoxide dismutase (SOD) mimetic and superoxide anion radical scavenger, effectively attenuated ERK1/2 activation in both cell lines. These results suggest the involvement of $15 \mathrm{~d}-\mathrm{PGJ}_{2}$-induced ROS generation as an initiating event of ERK1/2 activation and subsequent induction of apoptosis.

\section{3. $15 d-P G J_{2}$ Induces Acute Apoptosis in OS Cells}

We hypothesized that $15 \mathrm{~d}-\mathrm{PGJ}_{2}$ causes not only diminished cell proliferation, but also induction of apoptosis in OS cell lines. Thus, we performed Annexin V/PI staining and immunoblotting for the apoptotic marker proteins such as active caspase-7 and poly(ADPribose)-polymerase (PARP). The Annexin V/PI data indicated time-dependent activation in OS cell lines upon 15d-PGJ $J_{2}$ treatment (Figure $3 \mathrm{~A}$ ). Activation of apoptosis was slightly stronger in Saos-2 cells, this being in line with viability data (Figure 1A) and indicating higher sensitivity of Saos-2 towards $15 \mathrm{~d}_{-} \mathrm{PGJ}_{2}$ compared to U2-OS cells. Even in less sensitive U2-OS cells, we observed robust and fast activation of apoptosis, with $21 \%$ and $33.6 \%$ of apoptotic cells after a 12 and $24 \mathrm{~h}$ treatment, respectively. The percentage of cell in early apoptosis was quite constant in range from $6 \%$ to $8 \%$ for both cell lines, whereas the percentage of necrotic cells was insignificant in all samples (below 1.5\%). In Saos-2 cells, we detected $26.3 \%$ of apoptotic cells (in early and late apoptosis) at $12 \mathrm{~h}$, and $44 \%$ at $24 \mathrm{~h}$ of $15 \mathrm{~d}-\mathrm{PGJ}_{2}$ treatment. This was further supported by a clear time-dependent caspase- 7 and PARP cleavage in response to $15 \mathrm{~d}-\mathrm{PGJ}_{2}$ (Figure $3 \mathrm{~B}, \mathrm{C}$ ). Altogether, our data indicate strong and early activation of apoptosis in both $15 \mathrm{~d}-\mathrm{PGJ}_{2}$-treated OS cell lines. 

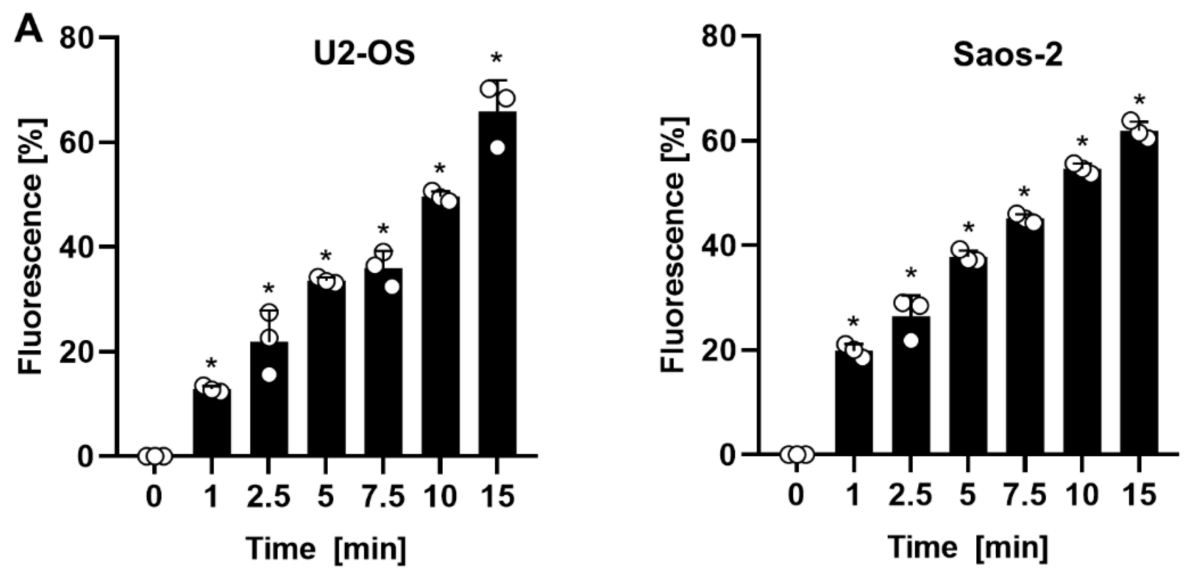

B U2-OS
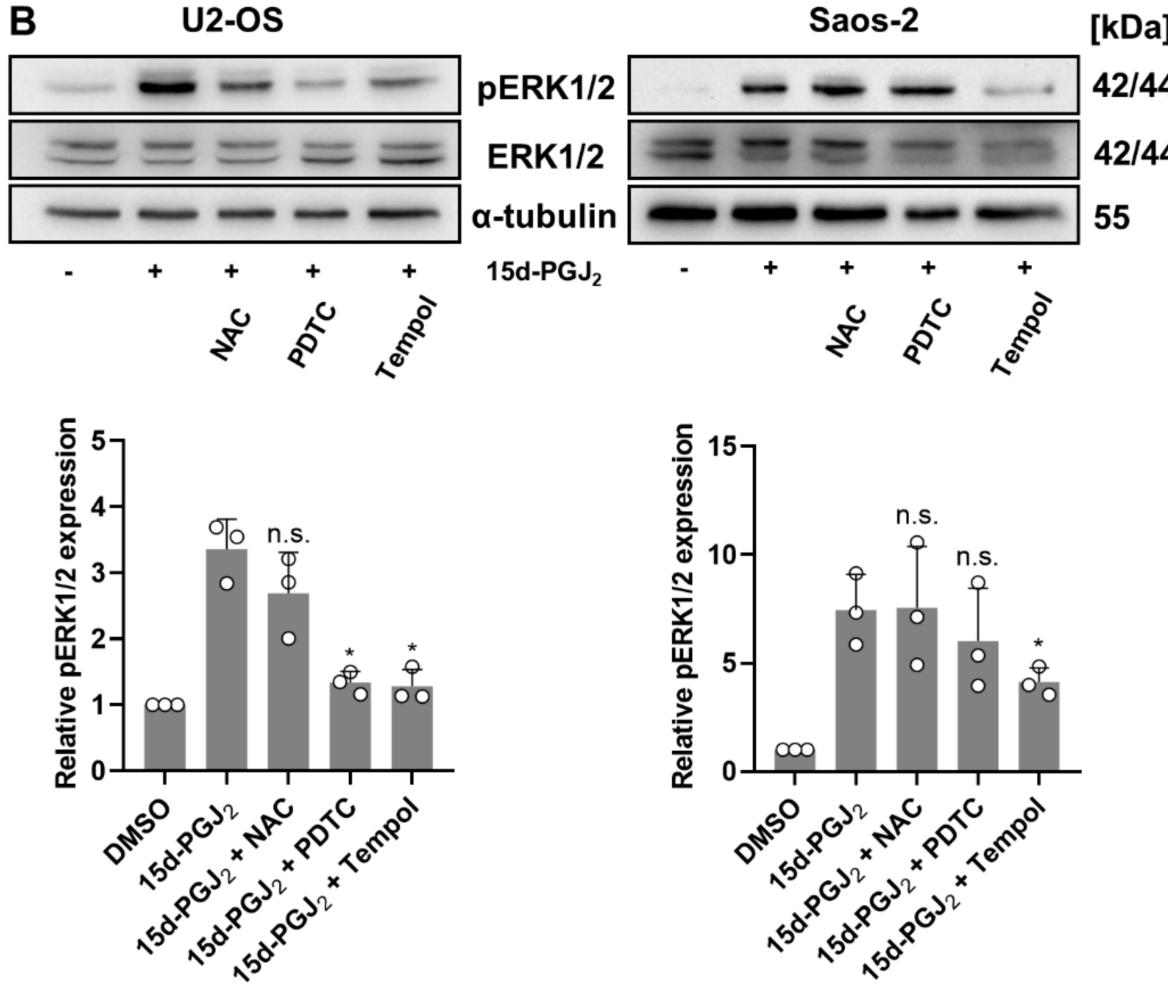

Figure 2. Induction of ROS production in OS cells treated with $15 \mathrm{~d}-\mathrm{PGJ}_{2}$. (A) Upon treatment of U2-OS (left panel) and Saos-2 (right panel) with 15d-PGJ 2 for indicated time periods, OS cells were incubated with the ROS-reactive carboxy- $\mathrm{H}_{2}$ DCFDA (5-(and -6)-carboxy-2 ${ }^{\prime}, 7^{\prime}$ dichlorodihydrofluorescein diacetate) dye. The resulting changes in fluorescence were measured and displayed as bar graph for each cell line. The data are represented as means $\pm \operatorname{SD}\left({ }^{*} p \leq 0.05\right)$ from three independent experiments. (B) Following a 30 min pre-incubation with ROS inhibitors (NAC (N-acetyl-cysteine), $15 \mu \mathrm{M}$; PDTC (pyrrolidine dithiocarbamate), $10 \mu \mathrm{M}$; Tempol, $10 \mu \mathrm{M}$ ), U2-OS (left panel) and Saos-2 (right panel) cells were exposed to the $20 \mu \mathrm{M} 15 \mathrm{~d}-\mathrm{PGJ}_{2}$ for $15 \mathrm{~min}$, followed by cell harvesting and lysis. The effects of the ROS inhibition on 15d-PGJ 2 -mediated intracellular MAPK activation (pERK1/2) were analyzed by immunoblotting experiments. One representative blot out of three is shown. Alpha-tubulin ( $\alpha$-tubulin) was used as a loading control (upper panel). Densitometric evaluation (lower panel) was based on at least three independent experiments and put in correlation to $\mathrm{pERK} 1 / 2$ expression in $15 \mathrm{~d}-\mathrm{PGJ}_{2}$-treated cells. Means $\pm \mathrm{SD}$ are shown. $\left({ }^{*} p \leq 0.05\right.$; n.s. = not significant). 

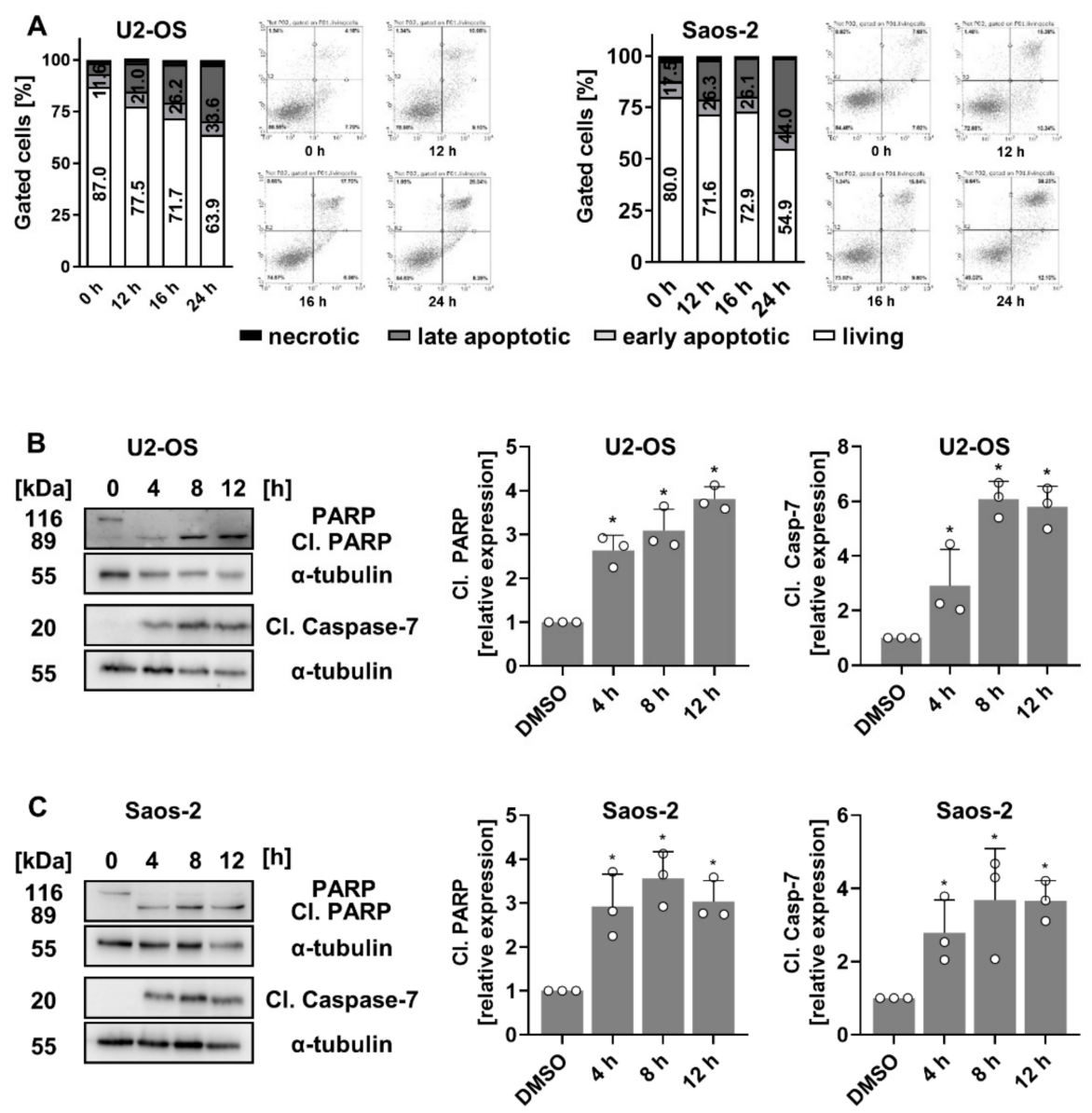<smiles>[2H]C1C=CC(C/C=C/CCCCCC)C1=C(C)CCCCC(=O)O</smiles>

E
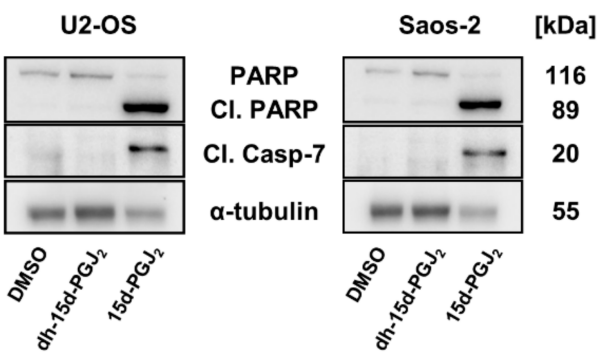

Figure 3. Induction of apoptosis in 15d-PGJ 2 -treated OS cell lines. (A) Following treatment of U2-OS (left panel) and Saos-2 cells (right panel) with $20 \mu \mathrm{M} 15 \mathrm{~d}-\mathrm{PGJ}_{2}$ for indicated time periods, OS cells were double-stained for Annexin V/PI and analyzed by FACS. Results are displayed in bar graphs and scatter plots for both OS cell lines. Numbers indicate percentage of viable cells (white bars) and cells in early and late apoptosis (sum of both light and dark gray bars) compared to all gated cells set to $100 \%$. One representative scatter plot from three independent experiments, each performed in triplicates, is shown. $(\mathbf{B}, \mathbf{C}) \mathrm{U} 2-\mathrm{OS}(\mathbf{B})$ and Saos-2 cells $(\mathbf{C})$ were treated with $15 \mathrm{~d}-\mathrm{PGJ} \mathrm{J}_{2}$ for indicated time periods. Afterwards, cells were harvested, lysed and the expression of cleaved PARP (Cl. PARP) and cleaved pro-caspase-7 ( $\mathrm{Cl}$. Caspase-7) was assessed from total protein lysates by immunoblotting. One representative blot with corresponding densitometric evaluation based on at least three blots are shown. Alpha-tubulin ( $\alpha$-tubulin) was used as a loading control. The data are compared to time point zero and represented as means \pm SD. $\left({ }^{*} p \leq 0.05\right)$ (D) Structural formula of $15 d-P G J_{2}$ and 9,10-dh-15d-PGJ the structural analogue lacking the electrophilic carbon atom C9. (E) U2-OS (left panel) and Saos-2 OS cells (right panel) were treated with $20 \mu \mathrm{M} 15 \mathrm{~d}-\mathrm{PGJ}_{2}$ or 9,10-dh-15d-PGJ $\mathrm{J}_{2}$ for $18 \mathrm{~h}$ and apoptosis markers (Cl. PARP and Cl. pro-caspase-7) were analyzed by immunoblotting. One representative blot out of three is shown. Alpha-tubulin ( $\alpha$-tubulin) was used as a loading control. 
Previously, we showed that 9,10-dihydro-15d-PGJ 2 (dh-15d-PGJ 2 ), the structural analogue of $15 \mathrm{~d}-\mathrm{PGJ}_{2}$, did not induce ROS-mediated cell death in MG-63 OS cells $[25,27]$. To test whether the 9,10 double bond in $15 \mathrm{~d}-\mathrm{PGJ}_{2}$ is a structural prerequisite (Figure $3 \mathrm{C}$ ) for its cytotoxic properties in OS cell lines, we compared activation of apoptosis in U2-OS and Saos-2 cells treated with either $15 \mathrm{~d}-\mathrm{PGJ}_{2}$ or dh-15d-PGJ ${ }_{2}$. As shown in Figure 3D, dh-15d-PGJ ${ }_{2}$ did not induce apoptosis in OS cells, indicating the functional importance of the cyclopentenone structure as an electrophilic mediator of cytotoxic cellular responses. These data show that the electrophilic carbon atom of $15 \mathrm{~d}-\mathrm{PGJ}_{2}$ is a prerequisite for $15 \mathrm{~d}-$ $\mathrm{PGJ}_{2}$-based cell toxicity and support previous findings obtained in osteoclasts and MG-63 OS cells $[17,25]$.

\section{4. $15 d-P G J_{2}$ Induces Time-Dependent MAPK Activation in OS Cells}

MAPK signaling cascades are activated in response to environmental stress signals and integrate cell fate decisions to induce survival or death pathways [28]. We aimed to analyze the effect of $15 \mathrm{~d}-\mathrm{PGJ}_{2}$ on the expression of MAPKs. Following the addition of $15 \mathrm{~d}-\mathrm{PGJ}_{2}$ we noticed a significant time-dependent increase in the phosphorylation/activation of the three members of the MAPK family, namely ERK1/2, p38 MAPK, and c-Jun N-terminal kinase (JNK) in both OS cell lines (Figure 4A). Next, we wanted to figure out whether these events have any effect on some of the pro-survival proteins as well as on pro-apoptosis intracellular protein responses. Therefore, OS cells were treated up to $8 \mathrm{~h}$ in order to identify changes in the phosphorylation of AKT, and expression of the basic leucine zipper transcription factor nuclear factor E2-related factor 2 (Nrf2), the zinc-finger transcription factor early growth response factor (Egr1), and nuclear factor NF-kappa B (NF-kB), respectively. We noticed a transient increase in AKT phosphorylation at 1 and $2 \mathrm{~h}$ that was significantly downregulated at later time points. Nrf2 and NF- $\mathrm{kB}$ expression was also induced at the earlier time points (up to 2-4 h), while Egr1 started to decrease at incubation times $>2 \mathrm{~h}$ (Figure 4B).

\subsection{5d-PGJ Inhibits OS Tumor Growth in the CAM Model}

To span the bridge between the in vitro and in vivo OS cellular models, we performed ex ovo CAM assay with both U2-OS and Saos-2 cell lines. For comparative purposes, MG-63 cells have been also included. Vehicle- or $15 \mathrm{~d}_{-} \mathrm{PGJ}_{2}$-treated cells were grafted onto the CAM and tumor area, proliferation, and morphology was monitored. We observed substantial tumor growth inhibition in tumors developed from all three OS cell lines (U2OS (A-B), Saos-2 (G-H), and MG-63 (M-N)) treated with 15d-PGJ 2 (Figure 5A,B). Not only was the tumor size was smaller, but the density of tumor tissue was even more decreased upon the $15 \mathrm{~d}-\mathrm{PGJ} \mathrm{J}_{2}$ treatment, as shown with the HE staining for U2-OS (Figure $5 \mathrm{~A}(\mathrm{a}, \mathrm{b})$ ), Saos-2 (Figure 5A(i,j)), and MG-63 (Figure 5A(o,p)) onplants. Quantification revealed that significantly smaller tumors formed from $15 \mathrm{~d}-\mathrm{PGJ}_{2}$ pre-treated U2-OS $(57 \%, p=0.0004)$, Saos-2 (38\%, $p=0.035)$, and MG-63 (35\%, $p=0.0015)$ cells compared to vehicle-pretreated cells (Figure $5 \mathrm{~B}$ ). We further analyzed the expression of the proliferation marker Ki-67 for U2-OS (Figure 5A(e,f)), Saos-2 (Figure 5A(k,l)), and MG-63 (Figure 5A(q,r)) onplants, which was significantly stronger in control, untreated tumors, indicating reduced cell proliferation of grafted 15d-PGJ 2 -treated OS cells. These results were comparable for all three OS cells. Possible model depicting the regulation of $15 \mathrm{~d}-\mathrm{PGJ}_{2}$-based activation of apoptosis in OS cells is shown in Figure 6. 
A

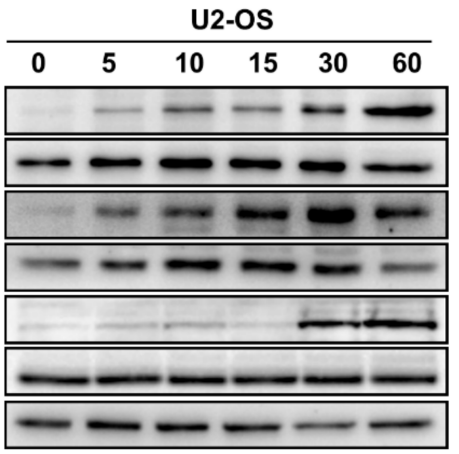

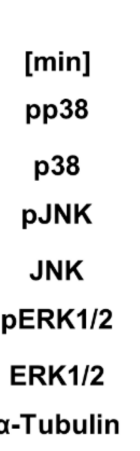
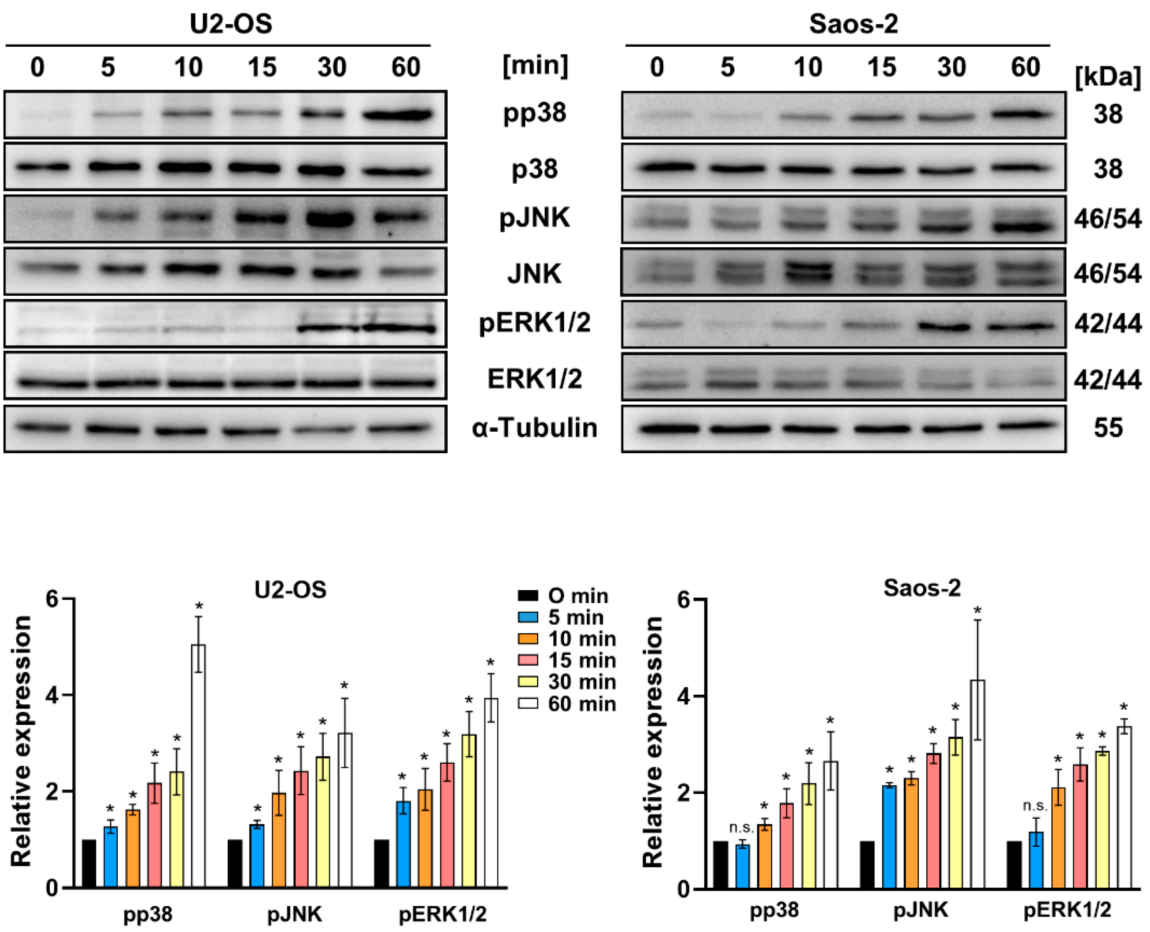

B
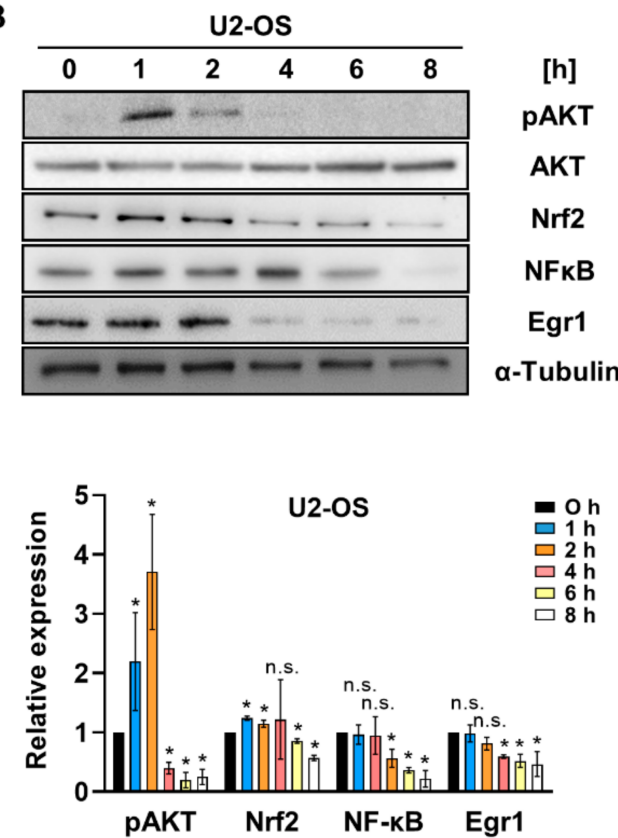
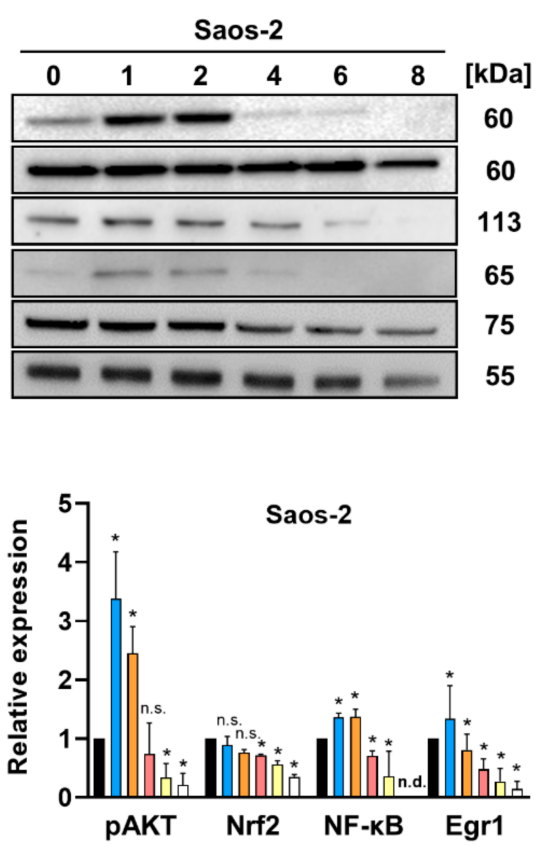

Figure 4. Activation of the MAPK pathway as an early downstream target of 15d-PGJ 2 . (A) U2-OS (left panel) and Saos-2 OS cells (right panel) were treated with $20 \mu \mathrm{M} 15 \mathrm{~d}-\mathrm{PGJ}_{2}$ for indicated time periods and time-dependent MAPK phosphorylation status was analyzed by immunoblotting. One representative blot with corresponding densitometric evaluation based on at least three experiments are shown below. Alpha-tubulin ( $\alpha$-tubulin) was used as a loading control. The data represented as means $\pm \mathrm{SD}$ are compared to time point zero. $\left({ }^{*} p \leq 0.05 ; \mathrm{n} . \mathrm{s} .=\right.$ not significant) (B) In order to assess whether the further downstream effects of $15 \mathrm{~d}-\mathrm{PGJ}_{2}$ include any cyto-protective mechanisms, immunoblots for antioxidant, pro-survival enzymes (AKT, Nrf2, NF- $\mathrm{kB}$, Egr1) were performed. One representative blot and densitometric evaluation of three independent experiments are shown (below). Alpha-tubulin ( $\alpha$-tubulin) was used as a loading control. The data represented as means $\pm \mathrm{SD}$ are compared to time point zero. $\left({ }^{*} p \leq 0.05 ;\right.$ n.s. $=$ not significant $) ;$ n.d. $=$ not detected. 
A

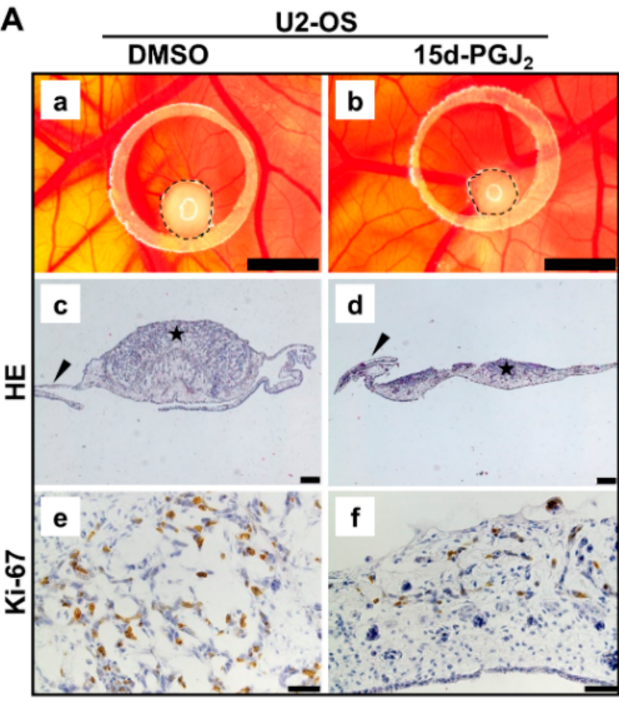

MG-63

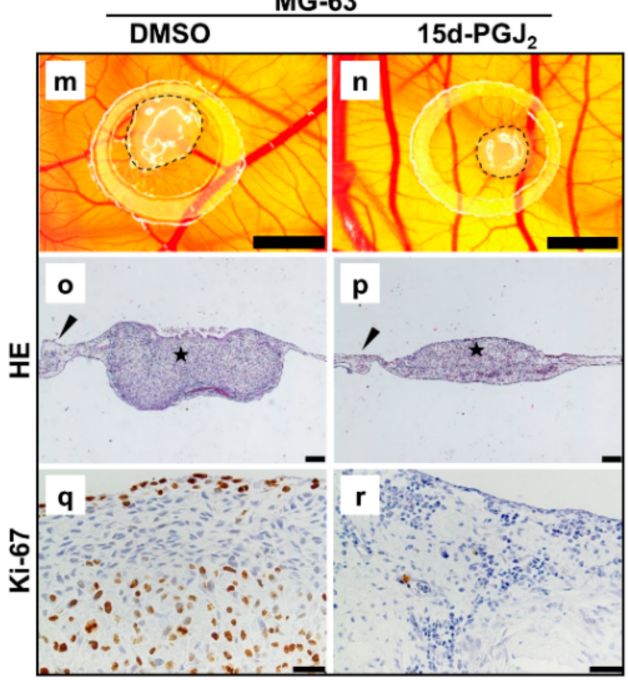

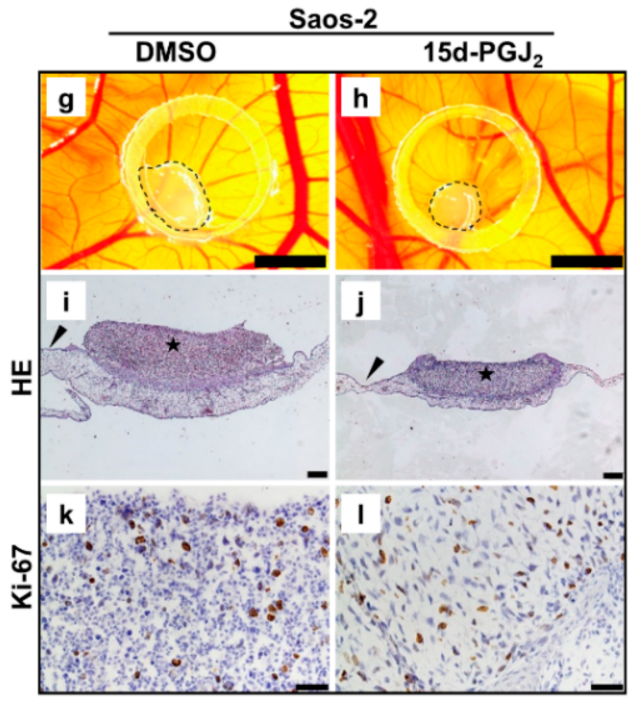

B

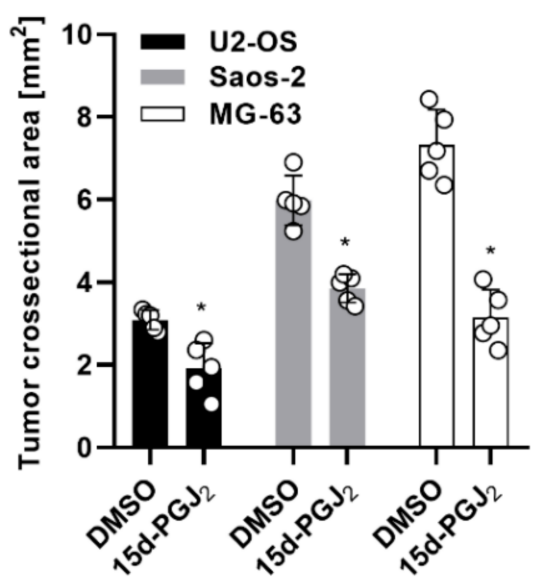

Figure 5. $15 \mathrm{~d}-\mathrm{PGJ}_{2}$ reduces cell proliferation in OS cells grafted ex ovo on chicken chorioallantoic membrane (CAM). (A) Representative images display U2-OS, Saos-2, and MG-63 OS xenografts treated with vehicle control (DMSO concentration corresponding to $20 \mu \mathrm{M} 15 \mathrm{~d}-\mathrm{PGJ}_{2}, 0.04 \% ; \mathrm{n}=5$ ) or with $20 \mu \mathrm{M} 15 \mathrm{~d}-\mathrm{PGJ}_{2}(\mathrm{n}=5)$. Microphotographs display differences in solid tumor formation for control (DMSO) and 15d-PGJ 2 -treated OS cells (U2-OS (a,b); Saos-2 (g,h); MG-63 (m,n)). Xenografts were photographed through a stereo microscope directly on cam (scale bar $=2 \mathrm{~mm}$ ). Haematoxylineosin (HE) staining of cross-sections of the xenografts display the inhibiting effect of $15 \mathrm{~d}-\mathrm{PGJ}_{2}$ on xenograft growth (U2-OS (c,d); Saos-2 (i,j); MG-63 (o,p)). Arrowheads are indicative for the CAM tissue, stars for the OS xenografts (scale bar $=200 \mu \mathrm{m}$ ). Immunohistochemical staining of the OS xenografts with anti Ki-67 antibody (U2-OS (e,f); Saos-2 (k,1); MG-63 (q,r)) shows the proliferation of OS cells on the CAM (scale bar $=20 \mu \mathrm{m}$ ). (B) Tumor size (crossectional area) was quantified by ImageJ. Data represent mean values $\left(\mathrm{mm}^{2}\right)$ and SD of five different tumors. Significance was estimated by $t$-test. ( $p \leq 0.05)$. 


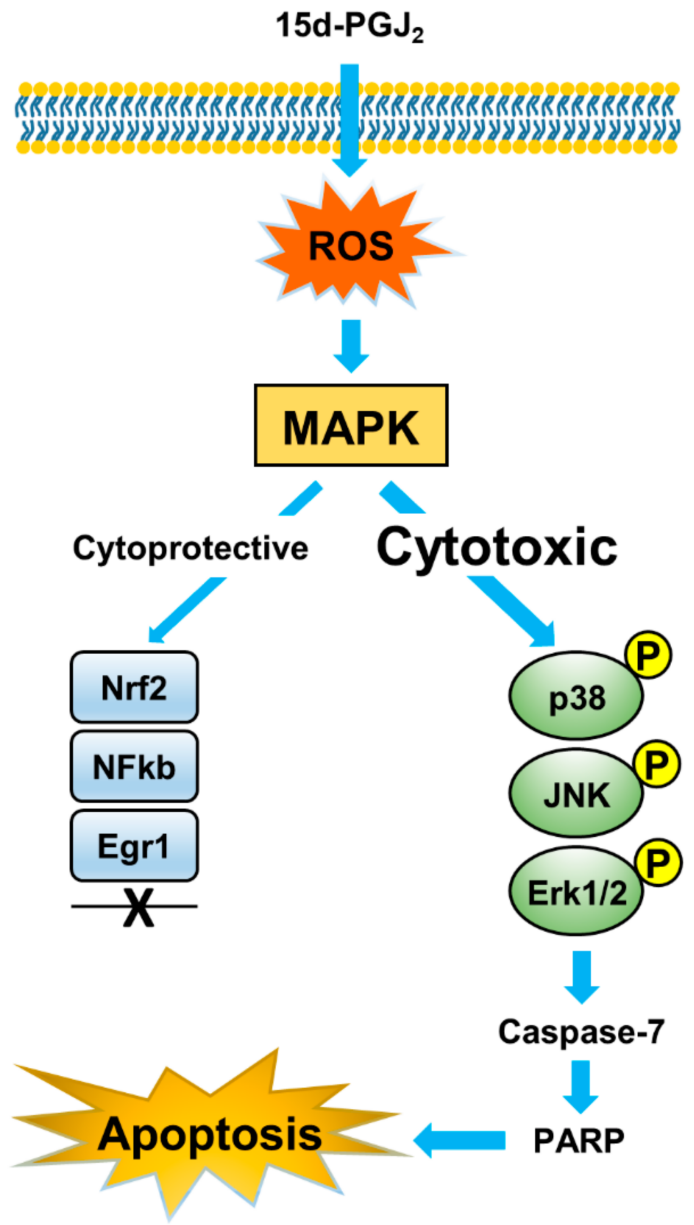

Figure 6. Model depicting the regulation of $15 \mathrm{~d}-\mathrm{PGJ}_{2}$-based apoptosis in OS cells. $15 \mathrm{~d}-\mathrm{PGJ} \mathrm{J}_{2}$ induces intracellular ROS production, thus activating MAPK-dependent apoptosis. Cytoprotective mechanism are transiently induced by $15 \mathrm{~d}-\mathrm{PGJ}_{2}$; however, they are quickly overwhelmed by apoptosis activation.

\section{Discussion}

OS is the most common tumor of bone [1,2]. Due to the late diagnosis and frequent formation of metastases, the establishment of an efficient pharmacological treatment is crucial. $15 \mathrm{~d}-\mathrm{PGJ}_{2}$ is a naturally occurring cyclopentenone PG in the human body [29], which can provide anti-inflammatory $[30,31]$ and anti-angiogenic $[30,32]$, but also proapoptotic [17,22-24] and anti-metastatic [33] properties in a variety of tissues and cell types. In this study, we aimed to elucidate acute effects and mechanisms of $15 \mathrm{~d}-\mathrm{PGJ}_{2}$ in different OS cell lines.

Previous studies in OS cells have shown inconclusive results suggesting the activation of pro-apoptotic and pro-survival mechanisms as a response to the treatment with $15 \mathrm{~d}-\mathrm{PGJ}_{2}[25,26]$. 15d-PGJ 2 increases ROS formation as one of the initial reactions to its anti-inflammatory and anti-tumor effects [26,29,34-37]. In this study, we found rapid activation of ROS formation upon 15d-PGJ 2 treatment of OS cells, followed by swift activation of MAPKs already within 5 to 15 min upon treatment of OS cells with $15 \mathrm{~d}-\mathrm{PGJ}_{2}$. Due to the potential dual role of a MAPK activation [38,39], we focused on a selection of proteins that are commonly increased when an intercellular survival mechanism is initiated [34,40-42]. In an earlier study, we could show that $15 \mathrm{~d}-\mathrm{PGJ}_{2}$ causes intracellular redox imbalance that further promotes both death and survival pathways in MG-63 OS cells [25]. The results of the present study revealed $15 \mathrm{~d}-\mathrm{PGJ}_{2}$-mediated ROS generation as an early event of a hierarchical series of cell fate decisions that culminate in OS cell apoptosis. Along this line, it is important to note that trabectedin, a semi-synthetic alkaloid originally isolated from 
the sea squirt Ecteinascidia Tunicata, in combination with irinotecan inhibits the growth of orthotopic osteosarcoma xenografts in mice that were established with pelvic OS biopsy material obtained from a 14-year-old patient [43]. A dose-escalation and dose-expansion study suggested that trabectedin i.v. in combination with the orally available PARP inhibitor olaparib shows manageable toxicity at active dose levels and promising preliminary data on antitumor potential in patients with bone and soft-tissue sarcomas [44,45]. In breast cancer and multiple myeloma cells trabectedin increased the generation of ROS and induced apoptosis [46] reminiscent of $15 \mathrm{~d}-\mathrm{PGJ}_{2}$-induced pathways observed during the present study.

Upon transient activation of pro-survival enzymes (Akt, Nrf2, NF-kB, and Egr1) their expression rapidly decreased to or below baseline levels. In accordance with our findings, Shin and colleagues reported rapid inactivation and degradation of Akt in $15 \mathrm{~d}-\mathrm{PGJ}_{2}$-treated leukemia cells that correlated with increased apoptosis susceptibility [29]. We observed a decrease in overall Nrf2 levels associated with increased apoptosis, compatible with findings reported for cisplatin-resistant MG-63 and Saos-2 cells [47]. Thus, we conclude that $15 \mathrm{~d}-\mathrm{PGJ}_{2}$-mediated activation of cytoprotective mechanism is quickly overcome by inhibition of cell proliferation and induction of apoptosis. This suggests that $15 \mathrm{~d}-\mathrm{PGJ} \mathrm{J}_{2}$ primarily acts as initiator of apoptosis in OS cell lines. Therefore, we suggest that in U2-OS and Saos-2 cells, the cytoprotective mechanisms are less pronounced compared to MG-63 cells [25], which might be dependent on the different genetic background of cells. Both U2-OS and Saos-2 cells are known for higher invasion and motility versus low-invasive MG-63 cells. In contrast, MG-63 cells display higher clonogenicity as compared to the other two cell lines [48-50].

ROS generation is considered a primary event during $15 \mathrm{~d}-\mathrm{PGJ}_{2}$-mediated cell death induction in leukemia and colorectal cells, with cytosolic NADPH oxidase and mitochondria (complex 1 and 3) being the major sources for ROS generation [29]. The use of catalase or EUK-134 (a salen-manganese complex antioxidants mimicking catalase activity) blocked PARP cleavage and significantly reduced the number of apoptotic Annexin V-positive cells [29]. Induction of oxidative stress can lead to the modification of redox-sensitive protein thiols that act as intracellular sensor systems. Within the concept of redox signaling, growing evidence suggests that the modification of specific sensor proteins conveys information on the state of cellular homeostasis. Thioredoxin (Trx) represents one of the prototypic thiol-sensitive redox sensors and plays an important role during the induction of cell death. In this scenario, apoptosis signaling kinase 1 (ASK1) forms an inactive complex with reduced Trx1 that inhibits homophilic interaction of ASK1, which is required for full enzymatic activity. However, oxidation of Trx1 leads to the dissociation of Trx1 from ASK1, which induces full kinase activity [51]. As a MAP3 kinase, ASK1 can then initiate downstream activation of $\mathrm{p} 38$ and JNK, both promoting the apoptotic machinery leading to cell death [52]. 15d-PGJ 2 , as an electrophile, is able to modify Trx thiols (Cys-35 and Cys-39) via Michael adduct formation [53]. In this study, the cleavage of both PARP and procaspase- 7 was not observed in dh-15d-PGJ 2 -treated cells, indicating that the electrophilic C9 in $15 \mathrm{~d}-\mathrm{PGJ}_{2}$ is a definitive moiety to induce OS cell apoptosis, a process most probably mediated via de-repression of the ASK1 signalosome and subsequent activation of the proapoptotic MAPK members p38 and JNK.

As a limitation of our study, we presently cannot exclude the influence of genetic background of different OS cells on effects caused by $15 \mathrm{~d}-\mathrm{PGJ}_{2}$, since MG-63 cells express functional $\mathrm{Rb}$ but not $\mathrm{p} 53$, U2-OS cells express both functional $\mathrm{Rb}$ and $\mathrm{p} 53$, while Saos-2 cells lack both $\mathrm{Rb}$ and $\mathrm{p} 53$ expression. Both, $\mathrm{Rb}$ and p53 play pivotal roles in cell fate decisions including cell cycle arrest, DNA damage response and apoptosis [54].

As a strength of our study, we analyzed some basic effects of $15 \mathrm{~d}-\mathrm{PGJ}_{2}$ on nonmalignant human osteoblasts expressing both intact p53 and Rb protein. Since our two model cell lines are both of osteoblastic origin $[55,56]$, we considered the human osteoblast cell line hFOB1.19 as a suitable model. Here, we show that non-malignant osteoblasts are 
characterized by higher resistance to $15 \mathrm{~d}-\mathrm{PGJ}_{2}$, this supporting the role of $15 \mathrm{~d}-\mathrm{PGJ}_{2}$ as a potential therapeutic agent.

$15 \mathrm{~d}-\mathrm{PGJ}_{2}$-based generation of ROS promotes $\mathrm{p} 38 \mathrm{MAPK}$ activation and subsequent Akt phosphorylation in MG-63 OS cells [25]. Here, we show that these mechanisms are of importance in different OS cell lines. Caused by $15 \mathrm{~d}-\mathrm{PGJ}_{2}$, cells produce ROS, which in turn phosphorylate MAPKs that in turn may activate downstream MAPK kinases. The p38and JNK-MAPK pathways in turn activate caspases for the successful completion of the apoptotic pathway. Therefore, the time-dependent increase in expression of the activated forms of these enzymes indicates a successful induction of apoptosis by $15 \mathrm{~d}-\mathrm{PGJ}_{2}$.

The CAM assay is an easily accessed system for studying the growth capability of grafted cells [48] and a suitable tool for preclinical screening of anticancer drugs. It can be much more easily and quickly established than animal models, it is relatively cheap, and does not need ethic committee approval [57]. A previous study, using a panel of eight different OS cell lines to induce tumor formation in the CAM assay, found medium tumor growth for U2-OS and Saos-2 cell lines but only moderate tumor growth with MG-63 cells [57]. We observed efficient formation of solid tumors using U2-OS, Saos-2, and MG-63 cells. The reasons for this discrepancy might be due to (i) differences in growth of onplanted OS cells between in ovo [57] and our ex ovo CAM models, and (ii) the number of onplanted cells which is different in both studies. Most importantly, our data show efficient growth inhibition in tumor onplants from $15 \mathrm{~d}-\mathrm{PGJ}_{2}$-pretreated OS cells. Both the tumor size and the density of tumor tissue was diminished upon cell treatment with $15 \mathrm{~d}-\mathrm{PGJ}_{2}$. As a method bridging the gap between in vitro and in vivo, the CAM model efficiently display pronounced cytotoxic effects of $15 \mathrm{~d}-\mathrm{PGJ}_{2}$ on OS cells, thus further identifying $15 \mathrm{~d}-\mathrm{PGJ}_{2}$ as a promising therapeutic agent against $O S$.

In conclusion, we found that $15 \mathrm{~d}-\mathrm{PGJ}_{2}$ has pronounced anti-tumorigenic effects on different OS cell lines. It activates increased ROS production, which further triggers a very rapid activation of apoptosis and inhibition of cell proliferation. These effects are more pronounced in malignant OS cells compared to non-malignant osteoblasts. In an ex vivo CAM assay, $15 \mathrm{~d}-\mathrm{PGJ}_{2}$ strongly attenuates OS tumor formation. Altogether, our results suggest $15 \mathrm{~d}-\mathrm{PGJ}_{2}$ as a very potent naturally occurring substance for treatment of osteosarcoma and facilitate further in vivo/clinical studies in this field.

\section{Materials and Methods}

\subsection{Materials}

15d-PGJ 2 (15-deoxy- $\Delta^{12,14}$-prostaglandin $\mathrm{J}_{2}$, \#18570, Cayman Chemical Company, Ann Arbor, MI, USA) was dissolved under sterile conditions in dimethyl sulfoxide (DMSO, Sigma-Aldrich, MO, USA). Aliquots $(20 \mathrm{mM})$ were stored at $-20^{\circ} \mathrm{C}$ and used within two weeks. If not otherwise stated, DMSO has been used as vehicle control at a concentration corresponding to $20 \mu \mathrm{M} 15 \mathrm{~d}-\mathrm{PGJ}_{2}(0.04 \%, v / v)$. All cell culture media and supplements were from Gibco (Thermo Fisher Scientific, Schwerte, Germany). Fetal calf serum (FCS, Thermo Fisher Scientific) was heat-inactivated in house $\left(56^{\circ} \mathrm{C}\right.$ for $\left.30 \mathrm{~min}\right)$.

\subsection{Cell Culture}

OS cell lines (U2-OS (HTB-06), Saos-2 (HTB-85), MG-63 (CRL-1427)) were of human origin (ATCC, Manassas, VA, USA). U2-OS and MG-63 cells were cultured in Eagle's Alpha-Minimal Essential medium (EMEM) supplemented with $2.5 \mathrm{mM}(w / v)$ L-glutamine, $10 \%(v / v)$ FCS, and 1\% $(v / v)$ penicillin/streptomycin (Gibco). Saos-2 cells were cultured in McCoy 5A medium (Lonza, Switzerland) supplemented with $2.5 \mathrm{mM}(w / v)$ L-glutamine, $10 \%(v / v) \mathrm{FCS}$, and $1 \%(v / v)$ penicillin/streptomycin. OS cell lines were cultivated under standardized conditions $\left(5 \% \mathrm{CO}_{2}, 37^{\circ} \mathrm{C}, 98 \%\right.$ humidity) and medium was exchanged twice per week. Human osteoblasts (hFOB1.19), provided by the Core Facility Alternative Biomodels \& Preclinical Imaging of the Medical University Graz, were cultivated at $34^{\circ} \mathrm{C}$ in a 1:1 $(v / v)$ mixture of Ham's F12 medium and Dulbecco's Modified Eagle's Medium (DMEM) supplemented with $2.5 \mathrm{mM}(w / v)$ L-glutamine, 10\% $(v / v) \mathrm{FCS}, 1 \%(v / v)$ peni- 
cillin/streptomycin, and $0.3 \mathrm{mg} / \mathrm{mL}$ G-418 (Geneticin, InvivoGen, Toulouse, France). All cell lines were split at $80-90 \%$ confluence and cell numbers were determined by CASY (OMNI Life Sciences, Bremen, Germany). The mycoplasma test was performed every three months.

\subsection{Proliferation and Viability Assay (MTT)}

Cells were treated in 12-well plates $\left(180,000\right.$ cells/well) with $20 \mu \mathrm{M} 15 \mathrm{~d}-\mathrm{PGJ}_{2}$, a suitable concentration reported previously in numerous studies [29,36,58-61], for indicated time periods $(4,18,24 \mathrm{~h})$ prior to a $30 \mathrm{~min}$ incubation with MTT (3-(4,5-dimethylthiazol2-yl)-2,5-diphenyltetrazolium bromide) ( $0.5 \mathrm{mg} / \mathrm{mL}$; dissolved in serum-free medium). Afterwards, the resulting insoluble dye formazan was made soluble by addition of $350 \mu \mathrm{L}$ acidic isopropanol $(0.04 \mathrm{M} \mathrm{HCl}$ in isopropanol). Samples were then further analyzed via optical measurement (with the emission/correction wavelengths of 570/630 nm) by using a microtiter plate reader (BMG Labtech, Ortenberg, Germany). The results were compared to the vehicle control $(0.04 \%)$ and assessed by appropriate statistics.

\subsection{Wound Healing Assay}

Wound healing assay was performed in order to investigate the influence of $15 \mathrm{~d}-\mathrm{PGJ} 2$ on cell proliferation and motility. Cells were seeded in cell culture inserts (Ibidi GmbH, Graefelfing, Germany) places in a 12-well plates and grown until approx. $90 \%$ confluence prior to incubation with $15 \mathrm{~d}-\mathrm{PGJ}_{2}$ for $24 \mathrm{~h}$. Afterwards, cell culture inserts were removed, leaving a defined $500 \mu \mathrm{m}$ cell-free gap, and medium was changed to remove detached cells. Cells treated with DMSO $(0.04 \%)$ were used as a vehicle control. Cell were then incubated at standardized conditions and photos were taken at time points $0,24,36$, and $48 \mathrm{~h}$ (Nikon ECLIPSE Ts2, 40× magnification). Gap closure was measured and quantified by Fiji ImageJ Wound Healing plug-in (open source) and calculated as percentage of the open gap area compared to the zero time point.

\subsection{Colony Formation Assay}

Cells were seeded in 6-well plates and treated with $20 \mu \mathrm{M} 15 \mathrm{~d}-\mathrm{PGJ}_{2}$ or corresponding vehicle concentration (DMSO, 0.04\%) for $24 \mathrm{~h}$. Afterwards, cells were trypsinized, counted, and the appropriate cell number (300 for U2-OS cells, 1000 for Saos-2 cells) was seeded into 6-well plates and incubated for additional 10 days (U2-OS) or 15 days (Saos-1). On the last day, colonies were fixed (methanol:glacial acetic acid; 3:1 (v/v)) and stained with $0.4 \%(w / v)$ aqueous crystal violet solution (C6158, Sigma). Colonies were then scanned on a white background and counting was performed by ImageJ with Colony Counter plug-in. Only colonies containing at least 50 cells were taken into account.

\subsection{Intracellular ROS Measurement}

Intracellular redox homeostasis was assessed as previously described by our group [25]. Briefly, U2-OS and Saos-2 cells were grown until a confluence of approx. $80 \%$ in 24 -well plates and treated with $20 \mu \mathrm{M} 15 \mathrm{~d}-\mathrm{PGJ}_{2}$. Cells were incubated with the ROS-reactive dye carboxy- $\mathrm{H}_{2}$ DCFDA (5-(and -6)-carboxy-2', $7^{\prime}$-dichlorodihydrofluorescein diacetate, Invitrogen) in phosphate-buffered saline (PBS) for $30 \mathrm{~min}$ at $37^{\circ} \mathrm{C}$. Afterwards, the cells were washed twice with ice-cold PBS and lysed with $300 \mu \mathrm{L}$ of 3\% (v/v) Triton X-100 in PBS for $30 \mathrm{~min}$, followed by a $15 \mathrm{~min}$ incubation in $50 \mu \mathrm{L}$ absolute ethanol with shaking (1350 rpm) at $4{ }^{\circ} \mathrm{C}$. Finally, samples were centrifuged at $10,000 \mathrm{rpm}$ at $4{ }^{\circ} \mathrm{C}$ to remove cell debris, and in supernatants the DCF $\left(2^{\prime}, 7^{\prime}\right.$-dichlorofluorescein) was measured at emission/correction wavelengths of 485/540 nm, respectively. A microtiter plate reader (CLARIOstar, BMG Labtech, Ortenberg, Germany) was used to measure fluorescence intensities.

\subsection{Immunoblot Analysis}

Treated cells were harvested and lysed in RIPA buffer (Sigma, R0278) containing protease inhibitor cocktail (A32953, Thermo Scientific) and phosphatase inhibitors (A32957, 
Thermo Scientific). Upon sonication $(2 \times 5 \mathrm{~s})$, soluble total proteins were separated by centrifugation at 13,000 rpm for $10 \mathrm{~min}$. Supernatants were collected total protein concentration was measured using BCA protein assay kit (Thermo Fisher Scientific). Protein extracts $(15 \mu \mathrm{g})$ were denatured for $10 \mathrm{~min}$ at $95{ }^{\circ} \mathrm{C}$, separated via electrophoresis on polyacrylamide gel, and transferred onto nitrocellulose or PVDF membranes $(0.45 \mu \mathrm{m}$, Amersham). The membranes were blocked with $5 \%(w / v)$ non-fat milk or bovine serum albumin (BSA) for $1 \mathrm{~h}$ at room temperature (RT, $25^{\circ} \mathrm{C}$ ), followed by an overnight incubation at $4{ }^{\circ} \mathrm{C}$ with the primary antibody. All antibodies and dilutions used in this study are summarized in Table 1. Afterwards, the membranes were washed in TBST three times for $10 \mathrm{~min}$ and incubated with appropriate secondary antibodies linked with horseradish peroxidase (HRP). Final development was performed with ECL Prime Western Blot Detection Reagents (Amersham) with signal detection on Chemi-Doc Touch Biorad device. Membranes were stripped with the Restore Plus Western blot stripping buffer (Thermo Fisher Scientific). For loading control, antibody raised against alpha tubulin ( $\alpha$-tubulin) was used. Intensity normalization to the loading control ( $\alpha$-tubulin) was performed by using Image Lab software 6.0.1 (Biorad).

Table 1. Primary antibodies and dilutions used in this study.

\begin{tabular}{clccc}
\hline Antibody & Company & Cat. Nr. & Host & Dilution \\
\hline pJNK & Cell Signaling & $\# 4668$ & rabbit & $1: 1000$ \\
JNK & Cell Signaling & $\# 9252$ & rabbit & $1: 2000$ \\
pp38 & Cell Signaling & $\# 9211$ & rabbit & $1: 1000$ \\
p38 & Cell Signaling & $\# 9212$ & rabbit & $1: 2000$ \\
p-Erk1/2 & Cell Signaling & $\# 9106$ & mouse & $1: 1000$ \\
Erk1/2 & Cell Signaling & $\# 9102$ & rabbit & $1: 2000$ \\
p-Akt (Ser473) & Cell Signaling & $\# 9271$ & rabbit & $1: 1000$ \\
Akt & Cell Signaling & $\# 9272$ & rabbit & $1: 2000$ \\
NF-kB (p56) & Cell Signaling & \#8242 & rabbit & $1: 1000$ \\
Egr1 & Cell Signaling & $\# 4154$ & rabbit & $1: 1000$ \\
Nrf2 & R\&D Systems & \#MAB3925 & mouse & $1: 500$ \\
PARP & Cell Signaling & rabbit & $1: 1000$ \\
Cl. Caspase-7 & Cell Signaling & $\# 9491$ & rabbit & $1: 1000$ \\
Alpha-tubulin & Cell Signaling & $\# 2125$ & rabbit & $1: 2000$ \\
\hline
\end{tabular}

\subsection{Annexine V/propidium Idodide (PI) Staining}

After reaching approx. $80 \%$ confluence, U2-OS and Saos-2 cells were treated with $20 \mu \mathrm{M} 15 \mathrm{~d}-\mathrm{PGJ}_{2}$ for 12, 18 and $24 \mathrm{~h}$. Cells were stained by FITC Annexin V Apoptosis Detection Kit 1 (BD Biosciences), followed by a wash in cold PBS, and a 15 min incubation at RT with a $100 \mu \mathrm{L}$ of $1 \times$ binding buffer ( $5 \mu \mathrm{L}$ of Annexin V FITC and $5 \mu \mathrm{L}$ of PI) in the dark. The results were obtained by cytometric analysis on the Guava EasyCyte 8 (Millipore) and analyzed by using the InCyte 3.1 software (Millipore).

\subsection{Ex Ovo Avian CAM Assay}

Chorioallantoic membrane (CAM) assay was carried out using the ex ovo CAM method according to Deryugina and Quigley [62]. Briefly, fertilized white Lohmann chicken eggs were cleaned and incubated at $37.5^{\circ} \mathrm{C}$ and $60 \%$ humidity (Incubator Easy 200, J. Hemel Brutgeraete, Verl, Germany). On day three of embryonic development, the egg shell was cracked in a sterile weigh boat and incubated at $37.5{ }^{\circ} \mathrm{C}$ and $60 \%$ humidity for further 6 days. On day nine of embryonic development, treated OS cells were grafted on CAM: OS cell lines (U2-OS, Saos-2, and MG-63) were grown until a confluence of approx. $80 \%$, treated with $20 \mu \mathrm{M} 15 \mathrm{~d}-\mathrm{PGJ}{ }_{2}$ or DMSO for $24 \mathrm{~h}$, and afterwards gently harvested by trypsinization. Silicone rings $(\varnothing 5 \mathrm{~mm})$ were carefully placed between embryonic blood vessels, and 15d-PGJ 2 -treated or control (DMSO) OS cell suspension was added into silicon rings $\left(1 \times 10^{6}\right.$ cells/onplant). The embryos were incubated again for four days and afterwards the onplants were harvested, fixed in $4 \%$ paraformaldehyde (PFA), dehydrated 
and embedded in paraffin. The paraffin tissue blocks were then cut into $7 \mu \mathrm{m}$ thick sections and fixed on glass tissue slides before immunohistochemical staining for the proliferation marker Ki-67.

\subsection{Immunohistochemistry}

Immunohistochemical staining for Ki-67 was performed in the automated system DAKO OMNIS with primary DAKO anti Ki-67 antibody Clone MIB-1 (GA62661-2) and DAKO OMNIS Flex HRP detection system. All slides were documented with the Nikon Eclipse E400 microscope and Zwo Asi 183 MC pro camera. Immunohistochemical staining was evaluated by two experienced histopathologists (MA, NGTW).

\subsection{Statistical Calculations}

All statistical calculations were performed by GraphPad Prism (v. 5.0). All values are represented as mean $\pm \mathrm{SD}$ of at least three independent experiments. A two-sided student's $t$-test was used to determine the level of statistical differences. A value of $p \leq 0.05$ was considered statistically significant $\left(^{*}\right)$.

Author Contributions: Conceptualization, M.M., N.G.T.-W., W.W., W.S., E.M. and A.H.; Data curation, M.M., E.M.B., M.A. and A.H.; Formal analysis, M.M., N.G.T.-W. and A.H.; Funding acquisition, E.M. and A.H.; Investigation, M.M., E.M.B. and C.T.; Methodology, M.M., N.G.T.-W., E.M.B., M.A., C.T. and A.H.; Project administration, E.M. and A.H.; Resources, E.M. and A.H.; Supervision, A.H.; Validation, M.M.; Visualization, M.M. and A.H.; Writing—original draft, M.M., N.G.T.-W., W.W., W.S., E.M. and A.H.; Writing—review and editing, M.M., N.G.T.-W., E.M.B., M.A., C.T., W.W., W.S., E.M. and A.H. All authors have read and agreed to the published version of the manuscript.

Funding: This research was funded by the Austrian National Bank (OeNB, Grant Number 17600 to E.M. and A.H.).

Institutional Review Board Statement: Not applicable.

Informed Consent Statement: Not applicable.

Data Availability Statement: All data generated and analyzed during this study are available from corresponding author on reasonable request.

Acknowledgments: We appreciate excellent technical assistance of Sandra Kickmaier, Jeannine Budinsky, and Julia Slanovc.

Conflicts of Interest: The authors declare no conflict of interest. The funders had no role in the design of the study; in the collection, analyses, or interpretation of data; in the writing of the manuscript, or in the decision to publish the results.

\section{Abbreviations}

$\begin{array}{ll}\text { OS } & \text { Osteosarcoma } \\ \text { PG } & \text { Prostaglandin } \\ \text { MAPK } & \text { Mitogen-activated protein kinase } \\ \text { ROS } & \text { Reactive oxygen species } \\ \text { CAM } & \text { Chorioallantoic membrane } \\ \text { DMSO } & \text { Dimethyl sulfoxide } \\ \text { EMEM } & \text { Eagle's minimum essential medium } \\ \text { DMEM } & \text { Dulbecco's Modified Eagle's Medium } \\ \text { FCS } & \text { Fetal calf serum } \\ \text { MTT } & \text { 3-(4,5-dimethylthiazol-2-yl)-2,5-diphenyltetrazolium bromide } \\ \text { H }{ }_{2} \text { DCFDA } & \text { 5-(and -6)-carboxy-2', } 7^{\prime} \text {-dichlorodihydrofluorescein diacetate } \\ \text { PBS } & \text { Phosphate-buffered saline } \\ \text { DCF } & \text { Dichlorofluorescein } \\ \text { BCA } & \text { Bicinchoninic acid assay }\end{array}$




$\begin{array}{ll}\text { PVDF } & \text { Polyvinylidene fluoride } \\ \text { BSA } & \text { Bovine serum albumine } \\ \text { TBST } & \text { Tris-buffered saline with Tween } 20 \\ \text { HRP } & \text { Horseradish peroxidase } \\ \text { RT } & \text { Room temperature } \\ \text { PFA } & \text { Paraformaldehyde } \\ \text { SD } & \text { Standard deviation } \\ \text { ERK1/2 } & \text { Extracellular signal-regulated kinase } \\ \text { NAC } & \text { N-acetyl-cystein } \\ \text { PDTC } & \text { Pyrrolidine dithiocarbamate } \\ \text { SOD } & \text { Superoxide dismutase } \\ \text { PARP } & \text { Poly(ADP-ribose)-polymerase } \\ \text { JNK } & \text { c-Jun N-terminal kinase } \\ \text { AKT } & \text { Protein kinase-B } \\ \text { Nrf2 } & \text { Nuclear factor E2-related factor 2 } \\ \text { Egr1 } & \text { Early growth response factor 1 } \\ \text { NF- } k \text { B } & \text { Nuclear factor NF-kappa B } \\ \text { Trx } & \text { Thioredoxin } \\ \text { ASK1 } & \text { Apoptosis signaling kinase 1 } \\ \text { Rb } & \text { Retinoblastoma }\end{array}$

\section{References}

1. Broadhead, M.L.; Clark, J.C.; Myers, D.E.; Dass, C.R.; Choong, P.F. The molecular pathogenesis of osteosarcoma: A review. Sarcoma 2011, 2011, 959248. [CrossRef]

2. Lindsey, B.A.; Markel, J.E.; Kleinerman, E.S. Osteosarcoma Overview. Rheumatol. Ther. 2017, 4, 25-43. [CrossRef]

3. Picci, P.; Mercuri, M.; Ferrari, S.; Alberghini, M.; Briccoli, A.; Ferrari, C.; Pignotti, E.; Bacci, G. Survival in high-grade osteosarcoma: Improvement over 21 years at a single institution. Ann. Oncol. 2010, 21, 1366-1373. [CrossRef]

4. Janeway, K.A.; Barkauskas, D.A.; Krailo, M.D.; Meyers, P.A.; Schwartz, C.L.; Ebb, D.H.; Seibel, N.L.; Grier, H.E.; Gorlick, R.; Marina, N. Outcome for adolescent and young adult patients with osteosarcoma: A report from the Children's Oncology Group. Cancer 2012, 118, 4597-4605. [CrossRef]

5. Anninga, J.K.; Gelderblom, H.; Fiocco, M.; Kroep, J.R.; Taminiau, A.H.; Hogendoorn, P.C.; Egeler, R.M. Chemotherapeutic adjuvant treatment for osteosarcoma: Where do we stand? Eur. J. Cancer 2011, 47, 2431-2445. [CrossRef] [PubMed]

6. Kempf-Bielack, B.; Bielack, S.S.; Jurgens, H.; Branscheid, D.; Berdel, W.E.; Exner, G.U.; Gobel, U.; Helmke, K.; Jundt, G.; Kabisch, H.; et al. Osteosarcoma relapse after combined modality therapy: An analysis of unselected patients in the Cooperative Osteosarcoma Study Group (COSS). J. Clin. Oncol. 2005, 23, 559-568. [CrossRef]

7. Whelan, J.S.; Jinks, R.C.; McTiernan, A.; Sydes, M.R.; Hook, J.M.; Trani, L.; Uscinska, B.; Bramwell, V.; Lewis, I.J.; Nooij, M.A.; et al. Survival from high-grade localised extremity osteosarcoma: Combined results and prognostic factors from three European Osteosarcoma Intergroup randomised controlled trials. Ann. Oncol. 2012, 23, 1607-1616. [CrossRef]

8. Wippel, B.; Gundle, K.R.; Dang, T.; Paxton, J.; Bubalo, J.; Stork, L.; Fu, R.; Ryan, C.W.; Davis, L.E. Safety and efficacy of high-dose methotrexate for osteosarcoma in adolescents compared with young adults. Cancer Med. 2019, 8, 111-116. [CrossRef]

9. Hattinger, C.M.; Patrizio, M.P.; Magagnoli, F.; Luppi, S.; Serra, M. An update on emerging drugs in osteosarcoma: Towards tailored therapies? Expert Opin. Emerg. Drugs 2019, 24, 153-171. [CrossRef]

10. Lilienthal, I.; Herold, N. Targeting Molecular Mechanisms Underlying Treatment Efficacy and Resistance in Osteosarcoma: A Review of Current and Future Strategies. Int. J. Mol. Sci. 2020, 21, 6885. [CrossRef]

11. Hikiji, H.; Takato, T.; Shimizu, T.; Ishii, S. The roles of prostanoids, leukotrienes, and platelet-activating factor in bone metabolism and disease. Prog. Lipid Res. 2008, 47, 107-126. [CrossRef]

12. Xie, C.; Ming, X.; Wang, Q.; Schwarz, E.M.; Guldberg, R.E.; O'Keefe, R.J.; Zhang, X. COX-2 from the injury milieu is critical for the initiation of periosteal progenitor cell mediated bone healing. Bone 2008, 43, 1075-1083. [CrossRef] [PubMed]

13. Zhang, X.; Schwarz, E.M.; Young, D.A.; Puzas, J.E.; Rosier, R.N.; O'Keefe, R.J. Cyclooxygenase-2 regulates mesenchymal cell differentiation into the osteoblast lineage and is critically involved in bone repair. J. Clin. Investig. 2002, 109, 1405-1415. [CrossRef]

14. Wang, D.; Dubois, R.N. Prostaglandins and cancer. Gut 2006, 55, 115-122. [CrossRef]

15. Gallant, M.A.; Samadfam, R.; Hackett, J.A.; Antoniou, J.; Parent, J.L.; de Brum-Fernandes, A.J. Production of prostaglandin D(2) by human osteoblasts and modulation of osteoprotegerin, RANKL, and cellular migration by DP and CRTH2 receptors. J. Bone Min. Res. 2005, 20, 672-681. [CrossRef]

16. Lin, T.H.; Tang, C.H.; Hung, S.Y.; Liu, S.H.; Lin, Y.M.; Fu, W.M.; Yang, R.S. Upregulation of heme oxygenase-1 inhibits the maturation and mineralization of osteoblasts. J. Cell Physiol. 2010, 222, 757-768. [CrossRef]

17. Yue, L.; Durand, M.; Lebeau Jacob, M.C.; Hogan, P.; McManus, S.; Roux, S.; de Brum-Fernandes, A.J. Prostaglandin D2 induces apoptosis of human osteoclasts by activating the CRTH2 receptor and the intrinsic apoptosis pathway. Bone 2012, 51, 338-346. [CrossRef] [PubMed] 
18. Uchida, K.; Shibata, T. 15-Deoxy-Delta(12,14)-prostaglandin J2: An electrophilic trigger of cellular responses. Chem. Res. Toxicol. 2008, 21, 138-144. [CrossRef] [PubMed]

19. Morgenstern, J.; Fleming, T.; Kadiyska, I.; Brings, S.; Groener, J.B.; Nawroth, P.; Hecker, M.; Brune, M. Sensitive mass spectrometric assay for determination of 15-deoxy-Delta(12,14)-prostaglandin J2 and its application in human plasma samples of patients with diabetes. Anal. Bioanal. Chem. 2018, 410, 521-528. [CrossRef]

20. Levonen, A.L.; Landar, A.; Ramachandran, A.; Ceaser, E.K.; Dickinson, D.A.; Zanoni, G.; Morrow, J.D.; Darley-Usmar, V.M. Cellular mechanisms of redox cell signalling: Role of cysteine modification in controlling antioxidant defences in response to electrophilic lipid oxidation products. Biochem. J. 2004, 378, 373-382. [CrossRef] [PubMed]

21. Kawakita, T.; Masato, N.; Takiguchi, E.; Abe, A.; Irahara, M. Cytotoxic effects of 15-deoxy-Delta12,14-prostaglandin J2 alone and in combination with dasatinib against uterine sarcoma in vitro. Exp. Med. 2017, 13, 2939-2945. [CrossRef] [PubMed]

22. Clay, C.E.; Monjazeb, A.; Thorburn, J.; Chilton, F.H.; High, K.P. 15-Deoxy-delta12,14-prostaglandin J2-induced apoptosis does not require PPARgamma in breast cancer cells. J. Lipid Res. 2002, 43, 1818-1828. [CrossRef]

23. Nakamura, M.; Tsumura, H.; Satoh, T.; Matsumoto, K.; Maruyama, H.; Majima, M.; Kitasato, H. Tumor apoptosis in prostate cancer by PGD(2) and its metabolite 15d-PGJ(2) in murine model. Biomed. Pharm. 2013, 67, 66-71. [CrossRef] [PubMed]

24. Shimada, T.; Kojima, K.; Yoshiura, K.; Hiraishi, H.; Terano, A. Characteristics of the peroxisome proliferator activated receptor gamma (PPARgamma) ligand induced apoptosis in colon cancer cells. Gut 2002, 50, 658-664. [CrossRef]

25. Koyani, C.N.; Kitz, K.; Rossmann, C.; Bernhart, E.; Huber, E.; Trummer, C.; Windischhofer, W.; Sattler, W.; Malle, E. Activation of the MAPK/Akt/Nrf2-Egr1/HO-1-GCLc axis protects MG-63 osteosarcoma cells against 15d-PGJ 2 -mediated cell death. Biochem. Pharm. 2016, 104, 29-41. [CrossRef] [PubMed]

26. Yen, C.C.; Hsiao, C.D.; Chen, W.M.; Wen, Y.S.; Lin, Y.C.; Chang, T.W.; Yao, F.Y.; Hung, S.C.; Wang, J.Y.; Chiu, J.H.; et al. Cytotoxic effects of $15 \mathrm{~d}-\mathrm{PGJ}_{2}$ against osteosarcoma through ROS-mediated AKT and cell cycle inhibition. Oncotarget 2014, 5, 716-725. [CrossRef]

27. Kitz, K.; Windischhofer, W.; Leis, H.J.; Huber, E.; Kollroser, M.; Malle, E. 15-Deoxy-Delta12,14-prostaglandin J2 induces Cox-2 expression in human osteosarcoma cells through MAPK and EGFR activation involving reactive oxygen species. Free Radic. Biol. Med. 2011, 50, 854-865. [CrossRef]

28. Wada, T.; Penninger, J.M. Mitogen-activated protein kinases in apoptosis regulation. Oncogene 2004, 23, 2838-2849. [CrossRef]

29. Shin, S.W.; Seo, C.Y.; Han, H.; Han, J.Y.; Jeong, J.S.; Kwak, J.Y.; Park, J.I. 15d-PGJ 2 induces apoptosis by reactive oxygen speciesmediated inactivation of Akt in leukemia and colorectal cancer cells and shows in vivo antitumor activity. Clin. Cancer Res. 2009, 15, 5414-5425. [CrossRef]

30. Bie, Q.; Dong, H.; Jin, C.; Zhang, H.; Zhang, B. 15d-PGJ 2 is a new hope for controlling tumor growth. Am. J. Transl. Res. 2018, 10, 648-658.

31. Straus, D.S.; Glass, C.K. Cyclopentenone prostaglandins: New insights on biological activities and cellular targets. Med. Res. Rev. 2001, 21, 185-210. [CrossRef]

32. Kim, E.H.; Kim, S.J.; Na, H.K.; Han, W.; Kim, N.J.; Suh, Y.G.; Surh, Y.J. 15-Deoxy-Delta(12,14)-prostaglandin J2 Upregulates VEGF Expression via NRF2 and Heme Oxygenase-1 in Human Breast Cancer Cells. Cells 2021, 10, 526. [CrossRef]

33. Diers, A.R.; Dranka, B.P.; Ricart, K.C.; Oh, J.Y.; Johnson, M.S.; Zhou, F.; Pallero, M.A.; Bodenstine, T.M.; Murphy-Ullrich, J.E.; Welch, D.R.; et al. Modulation of mammary cancer cell migration by 15-deoxy-delta(12,14)-prostaglandin J(2): Implications for anti-metastatic therapy. Biochem. J. 2010, 430, 69-78. [CrossRef] [PubMed]

34. Perillo, B.; Di Donato, M.; Pezone, A.; Di Zazzo, E.; Giovannelli, P.; Galasso, G.; Castoria, G.; Migliaccio, A. ROS in cancer therapy: The bright side of the moon. Exp. Mol. Med. 2020, 52, 192-203. [CrossRef]

35. Aggarwal, V.; Tuli, H.S.; Varol, A.; Thakral, F.; Yerer, M.B.; Sak, K.; Varol, M.; Jain, A.; Khan, M.A.; Sethi, G. Role of Reactive Oxygen Species in Cancer Progression: Molecular Mechanisms and Recent Advancements. Biomolecules 2019, 9, 735. [CrossRef] [PubMed]

36. Chen, K.; Dai, W.; Wang, F.; Xia, Y.; Li, J.; Li, S.; Liu, T.; Zhang, R.; Wang, J.; Lu, W.; et al. Inhibitive effects of 15-deoxyDelta(12),(14)-prostaglandin J2 on hepatoma-cell proliferation through reactive oxygen species-mediated apoptosis. OncoTargets Ther. 2015, 8, 3585-3593. [CrossRef]

37. Wang, J.J.; Mak, O.T. Induction of apoptosis by 15d-PGJ 2 via ROS formation: An alternative pathway without PPARgamma activation in non-small cell lung carcinoma A549 cells. Prostaglandins Other Lipid Mediat. 2011, 94, 104-111. [CrossRef] [PubMed]

38. Braicu, C.; Buse, M.; Busuioc, C.; Drula, R.; Gulei, D.; Raduly, L.; Rusu, A.; Irimie, A.; Atanasov, A.G.; Slaby, O.; et al. A Comprehensive Review on MAPK: A Promising Therapeutic Target in Cancer. Cancers 2019, 11, 1618. [CrossRef]

39. Dhillon, A.S.; Hagan, S.; Rath, O.; Kolch, W. MAP kinase signalling pathways in cancer. Oncogene 2007, 26, 3279-3290. [CrossRef]

40. Wang, B.; Guo, H.; Yu, H.; Chen, Y.; Xu, H.; Zhao, G. The Role of the Transcription Factor EGR1 in Cancer. Front. Oncol. 2021, 11, 642547. [CrossRef]

41. Shajahan-Haq, A.N.; Boca, S.M.; Jin, L.; Bhuvaneshwar, K.; Gusev, Y.; Cheema, A.K.; Demas, D.D.; Raghavan, K.S.; Michalek, R.; Madhavan, S.; et al. EGR1 regulates cellular metabolism and survival in endocrine resistant breast cancer. Oncotarget 2017, 8 , 96865-96884. [CrossRef] [PubMed]

42. Zimta, A.A.; Cenariu, D.; Irimie, A.; Magdo, L.; Nabavi, S.M.; Atanasov, A.G.; Berindan-Neagoe, I. The Role of Nrf2 Activity in Cancer Development and Progression. Cancers 2019, 11, 1755. [CrossRef] [PubMed] 
43. Higuchi, T.; Miyake, K.; Oshiro, H.; Sugisawa, N.; Yamamoto, N.; Hayashi, K.; Kimura, H.; Miwa, S.; Igarashi, K.; Chawla, S.P.; et al. Trabectedin and irinotecan combination regresses a cisplatinum-resistant osteosarcoma in a patient-derived orthotopic xenograft nude-mouse model. Biochem. Biophys. Res. Commun. 2019, 513, 326-331. [CrossRef] [PubMed]

44. Grignani, G.; D’Ambrosio, L.; Pignochino, Y.; Palmerini, E.; Zucchetti, M.; Boccone, P.; Aliberti, S.; Stacchiotti, S.; Bertulli, R.; Piana, R.; et al. Trabectedin and olaparib in patients with advanced and non-resectable bone and soft-tissue sarcomas (TOMAS): An open-label, phase 1b study from the Italian Sarcoma Group. Lancet Oncol. 2018, 19, 1360-1371. [CrossRef]

45. Perez, M.; Garcia-Heredia, J.M.; Felipe-Abrio, B.; Munoz-Galvan, S.; Martin-Broto, J.; Carnero, A. Sarcoma stratification by combined pH2AX and MAP17 (PDZK1IP1) levels for a better outcome on doxorubicin plus olaparib treatment. Signal Transduct. Target. Ther. 2020, 5, 195. [CrossRef]

46. Atmaca, H.; Bozkurt, E.; Uzunoglu, S.; Uslu, R.; Karaca, B. A diverse induction of apoptosis by trabectedin in MCF-7 (HER2-/ER+) and MDA-MB-453 (HER2+/ER-) breast cancer cells. Toxicol. Lett. 2013, 221, 128-136. [CrossRef] [PubMed]

47. Liu, Q.; Wang, K. The induction of ferroptosis by impairing STAT3/Nrf2/GPx4 signaling enhances the sensitivity of osteosarcoma cells to cisplatin. Cell Biol. Int. 2019, 43, 1245-1256. [CrossRef]

48. Sys, G.M.; Lapeire, L.; Stevens, N.; Favoreel, H.; Forsyth, R.; Bracke, M.; De Wever, O. The in ovo CAM-assay as a xenograft model for sarcoma. J. Vis. Exp. 2013, 77, e50522. [CrossRef]

49. Enomoto, M.; Hayakawa, S.; Itsukushima, S.; Ren, D.Y.; Matsuo, M.; Tamada, K.; Oneyama, C.; Okada, M.; Takumi, T.; Nishita, M.; et al. Autonomous regulation of osteosarcoma cell invasiveness by Wnt5a/Ror2 signaling. Oncogene 2009, 28, 3197-3208. [CrossRef]

50. Lauvrak, S.U.; Munthe, E.; Kresse, S.H.; Stratford, E.W.; Namlos, H.M.; Meza-Zepeda, L.A.; Myklebost, O. Functional characterisation of osteosarcoma cell lines and identification of mRNAs and miRNAs associated with aggressive cancer phenotypes. $\mathrm{Br}$. $J$. Cancer 2013, 109, 2228-2236. [CrossRef]

51. Matsuzawa, A. Thioredoxin and redox signaling: Roles of the thioredoxin system in control of cell fate. Arch. Biochem. Biophys. 2017, 617, 101-105. [CrossRef] [PubMed]

52. Son, Y.; Kim, S.; Chung, H.T.; Pae, H.O. Reactive oxygen species in the activation of MAP kinases. Methods Enzym. 2013, 528, 27-48. [CrossRef]

53. Shibata, T.; Yamada, T.; Ishii, T.; Kumazawa, S.; Nakamura, H.; Masutani, H.; Yodoi, J.; Uchida, K. Thioredoxin as a molecular target of cyclopentenone prostaglandins. J. Biol. Chem. 2003, 278, 26046-26054. [CrossRef]

54. Hickman, E.S.; Moroni, M.C.; Helin, K. The role of p53 and pRB in apoptosis and cancer. Curr. Opin. Genet. Dev. 2002, 12, 60-66. [CrossRef]

55. Mayr-Wohlfart, U.; Fiedler, J.; Gunther, K.P.; Puhl, W.; Kessler, S. Proliferation and differentiation rates of a human osteoblast-like cell line (SaOS-2) in contact with different bone substitute materials. J. Biomed. Mater. Res. 2001, 57, 132-139. [CrossRef]

56. Orimo, H.; Goseki-Sone, M.; Hosoi, T.; Shimada, T. Functional assay of the mutant tissue-nonspecific alkaline phosphatase gene using U2OS osteoblast-like cells. Mol. Genet. Metab. 2008, 94, 375-381. [CrossRef] [PubMed]

57. Balke, M.; Neumann, A.; Kersting, C.; Agelopoulos, K.; Gebert, C.; Gosheger, G.; Buerger, H.; Hagedorn, M. Morphologic characterization of osteosarcoma growth on the chick chorioallantoic membrane. BMC Res. Notes 2010, 3, 58. [CrossRef] [PubMed]

58. Kawahito, Y.; Kondo, M.; Tsubouchi, Y.; Hashiramoto, A.; Bishop-Bailey, D.; Inoue, K.; Kohno, M.; Yamada, R.; Hla, T.; Sano, H. 15-deoxy-delta(12,14)-PGJ(2) induces synoviocyte apoptosis and suppresses adjuvant-induced arthritis in rats. J. Clin. Investig. 2000, 106, 189-197. [CrossRef] [PubMed]

59. Doyle, K.; Fitzpatrick, F.A. Redox signaling, alkylation (carbonylation) of conserved cysteines inactivates class I histone deacetylases 1, 2, and 3 and antagonizes their transcriptional repressor function. J. Biol. Chem. 2010, 285, 17417-17424. [CrossRef]

60. Maier, N.K.; Leppla, S.H.; Moayeri, M. The cyclopentenone prostaglandin 15d-PGJ 2 inhibits the NLRP1 and NLRP3 inflammasomes. J. Immunol. 2015, 194, 2776-2785. [CrossRef]

61. Li, J.; Guo, C.; Wu, J. 15-Deoxy-(12,14)-Prostaglandin J2 (15d-PGJ 2$)$, an Endogenous Ligand of PPAR-gamma: Function and Mechanism. PPAR Res. 2019, 2019, 7242030. [CrossRef] [PubMed]

62. Deryugina, E.I.; Quigley, J.P. Chick embryo chorioallantoic membrane model systems to study and visualize human tumor cell metastasis. Histochem. Cell Biol. 2008, 130, 1119-1130. [CrossRef] [PubMed] 